\title{
Future changes in rainfall associated with ENSO, IOD and changes in the mean state over Eastern Africa
}

\author{
Hussen Seid Endris ${ }^{1,2}$ (I) $\cdot$ Christopher Lennard ${ }^{2} \cdot$ Bruce Hewitson $^{2} \cdot$ Alessandro Dosio $^{3}$ - Grigory Nikulin ${ }^{4}$. \\ Guleid A. Artan ${ }^{1}$
}

Received: 24 November 2017 / Accepted: 3 May 2018 / Published online: 10 May 2018

(c) The Author(s) 2018

\begin{abstract}
This study examines the projected changes in the characteristics of the El Niño Southern Oscillation (ENSO) and Indian Ocean Dipole (IOD) in terms of mean state, intensity and frequency, and associated rainfall anomalies over eastern Africa. Two regional climate models driven by the same four global climate models (GCMs) and the corresponding GCM simulations are used to investigate projected changes in teleconnection patterns and East African rainfall. The period 1976-2005 is taken as the reference for present climate and the far-future climate (2070-2099) under Representative Concentration Pathway 8.5 (RCP8.5) is analyzed for projected change. Analyses of projections based on GCMs indicate an El Niño-like (positive IOD-like) warming pattern over the tropical Pacific (Indian) Ocean. However, large uncertainties remain in the projected future changes in ENSO/IOD frequency and intensity with some GCMs show increase of ENSO/IOD frequency and intensity, and others a decrease or no/small change. Projected changes in mean rainfall over eastern Africa based on the GCM and RCM data indicate a decrease in rainfall over most parts of the region during JJAS and MAM seasons, and an increase in rainfall over equatorial and southern part of the region during OND, with the greatest changes in equatorial region. During ENSO and IOD years, important changes in the strength of the teleconnections are found. During JJAS, when ENSO is an important driver of rainfall variability over the region, both GCM and RCM projections show an enhanced La Niña-related rainfall anomaly compared to the present period. Although the long rains (MAM) have little association with ENSO in the reference period, both GCMs and RCMs project stronger ENSO teleconnections in the future. On the other hand, during the short rains (OND), a dipole future change in rainfall teleconnection associated with ENSO and IOD is found, with a stronger ENSO/IOD related rainfall anomaly over the eastern part of the domain, but a weaker ENSO/IOD signal over the southern part of the region. This signal is consistent and robust in all global and regional model simulations. The projected increase in OND rainfall over the eastern horn of Africa might be linked with the mean changes in SST over Indian and Pacific Ocean basins and the associated Walker circulations.
\end{abstract}

Keywords CORDEX $\cdot$ CMIP5 $\cdot$ Teleconnections $\cdot$ Eastern Africa $\cdot$ Rainfall $\cdot$ RCM

Electronic supplementary material The online version of this article (https://doi.org/10.1007/s00382-018-4239-7) contains supplementary material, which is available to authorized users.

Hussen Seid Endris

hussen.seid1@gmail.com

1 IGAD Climate Prediction and Applications Centre (ICPAC), Nairobi, Kenya

2 Climate System Analysis Group, University of Cape Town, Cape Town, South Africa

3 European Commission Joint Research Centre, Ispra, Italy

4 Rossby Centre, Swedish Meteorological and Hydrological Institute, Norrköping, Sweden

\section{Introduction}

Rainfall in the eastern Africa exhibits considerable variability across in space and time. This variability is a result of complex interactions between various features acting at local and global scales. The northern part of the region, mainly northern Ethiopia, Eritrea, South Sudan, Djibouti and northern Uganda receive most of their rainfall from June-to-September (JJAS). The equatorial part of the Eastern Africa experiences two rainy seasons during the course of the year, and this traditionally defined as 'long-rains' during Marchto-May (MAM) and 'short-rains' during October-December (OND). 
The interannual and intraseasonal variability of rainfall over the region is modulated by remote forcings. On interannual time scales, the short rains (OND) show large yearto-year variability and stronger spatial coherence of rainfall anomalies across a large part of the region, which strongly related to large-scale circulation anomalies in the tropical Oceans (Hastenrath et al. 1993, 2004; Saji et al. 1999; Philippon et al. 2002). The long rains exhibit inconsistent spatial variability and are weakly correlated to global sea surface temperatures (SSTs) (Nicholson 1996; Camberlin and Philippon 2002a, b; Camberlin et al. 2009a, b). In recent decades, much of eastern Africa has experienced more frequent droughts and a decline in total rainfall during the longrains season (Verdin et al. 2005; Funk et al. 2008, 2014; Williams and Funk 2011; Lyon and DeWitt 2012; Liebmann et al. 2014; Rowell et al. 2015; Tierney et al. 2015), although global climate models projections generally indicate wetter conditions in the future (Yang et al. 2014; Tierney et al. 2015). This contradiction has been named the 'East African climate paradox' (Rowell et al. 2015).

Some studies have been performed to understand the causes and drivers of the recent downward trend in rainfall during the long-rains. Funk et al. (2008) linked the negative trend in rainfall with positive trend in SST in the south central Indian Ocean, which alters regional wind and moisture flux patterns. Williams and Funk (2011) related drying conditions in East Africa with enhanced Indian-Pacific SST gradient and westward expansion of the warm pool. Studies by Lyon and DeWitt (2012), Lyon (2014), Yang et al. (2014) and Vigaud et al. (2017) linked the drying to changes in SSTs in tropical Pacific basin, whereas Liebmann et al. (2014, 2017) suggested the strengthening east-west SST gradient in the western Pacific as cause for the precipitation decline. They suggest that the change in the gradient intensifies the Indian Ocean branch of the Walker circulation, which, in turn leads to increase subsidence over eastern Africa, as shown in Funk et al. 2014. A recent paper by Nicholson (2017) provides a detail review of the factors leading to the recent decline in rainfall of the long-rains season and other aspects of the climate over eastern Africa.

The primary driver of JJAS rainfall variability in the northern part of eastern has been associated with tropical ocean SSTs in the Equatorial Pacific and ENSO (e.g., Camberlin 1997; Korecha and Barnston 2007; Segele et al. 2009a; Diro et al. 2011). Over all, a large percentage of the interannual rainfall variability of Eastern Africa is linked with SST variability particularly over the Equatorial Pacific and Indian Ocean through ENSO and the IOD. Ropelewski and Halpert (1987), Ogallo et al. (1988) and Indeje et al. (2000) among others have studied the link between SST over the Pacific and the interannual rainfall variability over Eastern Africa. Mutai et al. (1998), Nicholson and Kim (1997) and Clark et al. (2003) showed the influence of IOD on the variability of short rains over the region. The relationship between ENSO and summer (JJAS) rainfall variability has been investigated in studies by Gissila et al. (2004), Korecha and Barnston (2007), Segele et al. (2009a) and Diro et al. (2011).

Although several studies have investigated the historical teleconnection relationships between Eastern Africa rainfall patterns and large-scale climate modes (e.g. Ropelewski and Halpert 1987; Ogallo et al. 1988; Indeje et al. 2000; Diro et al. 2011; Bahaga et al. 2015; Endris et al. 2016), there is a lack of understanding as to whether or not the present teleconnection patterns will persist under future global warming. In fact, as a result of increased greenhouse gases concentrations, climate process behaviors and associations are understood to be potentially non-stationary and, as a consequence it is possible that ENSO/IOD characteristics and forcing could change overtime. Several studies have examined the future state of the tropical Oceans and the associated teleconnections under warming scenarios. There is a general agreement that the mean state in tropical Pacific will shift towards a permanent El Niño-like state, meaning greater surface warming over central and eastern equatorial Pacific than western Pacific, with a corresponding eastward shift of precipitation (IPCC 2007, Müller and Roeckner 2008, IPCC 2013). However, considerable disagreements remain in the model-projected changes in ENSO characteristics particularly in amplitude and frequency. Using the National Center for Atmospheric Research Community Climate System Model (CCSM; version 1.4), Zelle et al. (2005) looked at the changes in ENSO pattern due to an increase in greenhouse gases and found that there are no significant changes in ENSO amplitude, period and spatial patterns in the future. By using 15 Coupled Global Climate Models (CGCMs) gathered for the Intergovernmental Panel on Climate Change (IPCC) Fourth Assessment Report (AR4), Merryfield (2006) showed a decrease in El Niño amplitude in some models, but an increase or little change in others models. Collins et al. (2010) further suggested that it is not yet possible to say whether ENSO activity will be enhanced or dampened (or whether the frequency of events will change), despite considerable progress in the understanding of the impact of climate change on many of the processes that contribute to El Niño variability. Cai et al. (2014a, b) suggested evidence for a doubling in the occurrences of extreme El Niño events in the future in response to greenhouse warming by analyzing results from both CMIP3 and CMIP5 multi-model datasets. The study stated that the increased frequency in extreme El Niño events arises from a projected SST warming over the eastern equatorial Pacific that occurs faster than in the surrounding Ocean waters, facilitating more occurrences of atmospheric convection in the eastern 
equatorial region. Recent studies have also projected an increase in the frequency of extreme La Niña events under global warming (e.g., Cai et al. 2015; Santoso et al. 2015).

In terms of changes in SST over tropical Indian Ocean, some studies have shown that future global warming leads to a mean state change in the equatorial Indian Ocean, with an easterly wind change and a faster warming rate in the western parts of the Ocean without a noticeable change in overall frequency or amplitude of IOD events (Vecchi and Soden 2007; Zheng et al. 2013; Cai et al. 2013). However, Cai et al. (2014a, b) used a suite of distinct process-based indicators to show a significant increase in the frequency of the extreme positive IOD events under global warming. The study projected more frequent occurrences of wind and Oceanic current reversal due to an enhanced west-east SST gradient and weakening of both equatorial westerly winds and eastward ocean currents.

It is not clear whether the lack of consensus in future changes in ENSO/IOD characteristics is due to model deficiencies or to the fact that these changes will likely be small (Steinhoff et al. 2015). However, even without significant changes in ENSO/IOD characteristics (i.e. intensity and frequency), the long-term trend in tropical SST (change in the mean state) and the associated changes in atmospheric circulations (e.g., poleward expansions of the Hadley cell, shift of convergence zones, mid-latitude jets and storm tracks, etc.) may result in substantial changes in ENSO/IOD-related teleconnections (Meehl et al. 2006; Meehl and Teng 2007; Lau et al. 2008; Kug et al. 2010; Stevenson et al. 2012, IPCC 2013). This means that if teleconnective forcings associated with ENSO and IOD change, even if ENSO and IOD characteristics do not, rainfall characteristics are likely to change in regions with strong ENSO/IOD responses. Investigating the future changes in regional rainfall patterns associated with ENSO and IOD is therefore crucial in understanding the region changing vulnerability to extreme climate. This will likely help to build appropriate risk management and adaptation strategies for the region. This is particularly crucial for the Eastern Africa region, where the economy is highly dependent on agricultural based activities such as farming and livestock, which are sensitive to the fluctuations of rainfall.

Several regional modeling studies have shown that RCMs are able to reproduce the East African observed rainfall climatology and regional circulation patterns (e.g., Sun et al. 1999; Segele et al. 2009b; Endris et al. 2013; Ogwang et al. 2016) and also the interannual rainfall variability associated with global large-scale modes (Anyah and Semazzi 2007; Endris et al. 2016). Moreover, RCMs are found to be able to reproduce the observed long term drying trend of the long-rains season over most of the Eastern Africa region (Cook and Vizy 2013), contrary to the GCM that show wetter conditions. In fact, the coarse resolution of current GCMs can limit their capability in capturing the important local/regional forcing features such as complex topography, regional water bodies, land surface heterogeneity and coastlines (Cook and Vizy 2013; Endris et al. 2013; Ogwang et al. 2016).

The main goal of this study is to examine projected changes in the characteristics of ENSO and IOD (such as the mean state, intensity and frequency), and identify whether the current seasonal rainfall anomalies associated with ENSO and IOD over Eastern Africa are projected to change in the late twenty-first century. The work is the part of a series of three papers investigating Eastern African climate using data from the COordinated Regional climate Downscaling EXperiment (CORDEX). The first work (Endris et al. 2013) evaluated the ability of 10 Regional Climate Models (RCMs) driven by reanalysis data in simulating the characteristics of rainfall patterns over eastern Africa. The study showed that most RCMs reasonably simulate the main features of the rainfall climatology over the region, and in most of the areas and time periods, the multimodel ensemble mean outperforms the results of individual models, even the forcing ERA-Interim. The second work (Endris et al. 2016) examined the ability of two RCMs, forced with lateral and surface boundary conditions of Global Climate Models (GCMs) participating to the phase 5 Coupled Model Intercomparison Project (CMIP5), to propagate the teleconnective forcing of tropical SSTs on rainfall over East Africa. The study showed that RCMs are capable of reproducing the observed teleconnective SST-rainfall patterns, and that most errors in simulating the regional teleconnection patterns arise mainly from the driving GCMs. In this analysis, we have used the same models as in Endris et al. (2016) to quantify the projected seasonal rainfall change associated with ENSO and IOD over East Africa.

The paper is structured as follows: Sect. 2 provides a brief introduction to CORDEX and CMIP5 models as well as the approach used to evaluate the changes in teleconnection patterns in projection of the future climate. The main results are presented in Sect. 3. Summary and conclusions are presented in Sect. 4.

\section{Data and methodology}

\subsection{Models and experiments}

We have used monthly output from two RCMs in the ongoing CORDEX project, namely, the Rossby Center regional atmospheric model (RCA4), and the COnsortium for Smallscale MOdeling (COSMO) Regional Climate Limited-area Model (COSMO-CLM4-8-17 or CCLM4-8-17). Model choice was based on (1) the availability of the model outputs at the time of the analysis and (2) the relatively large number 
of common GCMs used as forcing boundary conditions. The two models were driven by the same four CMIP5 GCMs (CNRM-CM5, EC-EARTH, HadGEM2-ES and MPI-ESMLR). Details of the driving GCMs and their resolution are shown in Table 1.

The two models were run over the CORDEX-Africa domain (see Nikulin et al. 2012; Endris et al. 2013) with a horizontal grid spacing of 0.44 degrees. The historical simulations, covering the period 1950-2005, were forced by observed natural and anthropogenic atmospheric composition changes. Twenty-first century GCM simulations (2006-2100) were forced by Representative Concentration Pathways (RCPs-Moss et al. 2010) and in this analysis we use results from the RCP8.5 experiment, which represents a high concentration pathway in which radiative forcing reaches $8.5 \mathrm{Wm}^{-2}$ by 2100 , and then continues to rise thereafter (Meinshausen et al. 2011). In terms of $\mathrm{CO}_{2}$ concentration, RCP8.5 is roughly corresponding to the A1B scenarios used in the IPCC AR4, respectively (IPCC 2007).

In this analysis, the period 1976-2005 is considered as reference for present climate while projected analysis is performed for the far future (2070-2099). The performance of the models in reproducing the rainfall reference climatology and teleconnection patterns over Eastern Africa have been reported in Endris et al. (2013) and Endris et al. (2016), respectively, and therefore it is not presented here. However, a thorough analysis on the characteristics of ENSO and IOD events (frequency and intensity of ENSO and IOD events) is still missing in Endris et al. (2016) and it is therefore an additional subject of this study. The observed Oceanic Niño index (ONI) and Dipole Mode Index (DMI) indices in this analysis are calculated using the Extended Reconstructed Sea Surface Temperature-ERSST.v3b (Smith et al. 2008). Our analysis focuses on seasonal time periods that are important for rainfall over the region, June-September (JJAS), March-May (MAM) and October-December (OND) seasons. JJAS is the main rainfall season for the northern

Table 1 List of CORDEX RCMs and the driving CMIP5 GCMs used

\begin{tabular}{|c|c|c|c|c|}
\hline \multirow[t]{2}{*}{ CGCMs } & \multirow{2}{*}{$\begin{array}{l}\text { CGCMs } \\
\text { Horizontal } \\
\text { resolution }\end{array}$} & \multicolumn{2}{|c|}{ RCMs } & \multirow{2}{*}{$\begin{array}{l}\text { Institute and } \\
\text { country }\end{array}$} \\
\hline & & $\mathrm{RCA}$ & CCLM & \\
\hline CNRM-CM5 & $1.4 \times 1.4^{\circ}$ & $\checkmark$ & $\checkmark$ & CNRM, France \\
\hline EC-EARTH & $1.125 \times 1.12^{\circ}$ & $\checkmark$ & $\checkmark$ & $\begin{array}{l}\text { European con- } \\
\text { sortium }\end{array}$ \\
\hline HadGEM2-ES & $1.875 \times 1.25^{\circ}$ & $\checkmark$ & $\checkmark$ & $\begin{array}{l}\text { MOHC, United } \\
\text { Kingdom }\end{array}$ \\
\hline MPI-ESM-LR & $1.9 \times 1.9^{\circ}$ & $\checkmark$ & $\checkmark$ & MPI, Germany \\
\hline
\end{tabular}

Only the first ensemble member (r1i1p1) from the CMIP5 GCMs was used to derive the CORDEX Africa simulations with the exception of the EC-EARTH (i.e., r12i1p1 used). The datasets were obtained from the Earth System Grid Federation (ESGF) data portal part of Eastern Africa (NEA) covering South Sudan, most of the Ethiopian highlands, and parts of Sudan and Eritrea. MAM and OND are important rainfall seasons for the equatorial part of Eastern Africa (EEA) including Somalia, Kenya, Uganda, and South Eastern parts of Ethiopia, and for the Southern part of Eastern Africa (SEA) covering much of Tanzania, Rwanda, Burundi and Southern Kenya.

\subsection{Methodology}

Linear regression and composite analysis are applied to assess the changes in teleconnection patterns in projection of the future climate. Linear regression is commonly used to diagnose the relationship between SSTs and rainfall. In particular, it is important to examine the amplitude of rainfall teleconnections as shown by Langenbrunner and Neelin (2013) and Endris et al. (2016). One limitation of regression analysis is that it assumes that the response to SST (e.g. ENSO) is linear. This means that the anomalies in the El Niño phase are depicted as the opposite of those in the La Niña phase. Composite analysis is a useful alternative that can diagnose the asymmetry or nonlinearty of rainfall response to SST anomlies.

In this study, statistics are calculated over thirty years periods, 1976-2005 for historical and 2070-2099 for future. Linear regression is applied to analyze the association of spatial and amplitude of rainfall teleconnection with ENSO and IOD in historical and future periods. For ENSO, Nino3.4 index (Trenberth 1997), an average of SST over $5^{\circ} \mathrm{S}-5^{\circ} \mathrm{N}$ and $170^{\circ}-120^{\circ} \mathrm{W}$, is used to compute the teleconnections. For IOD, Dipole Mode Index (DMI) [Saji et al. 1999] is used, which is the difference between the area average SST in the western equatorial Indian Ocean $\left(50^{\circ}-70^{\circ} \mathrm{E}\right.$ and $\left.10^{\circ} \mathrm{S}-10^{\circ} \mathrm{N}\right)$ and southeastern equatorial Indian Ocean $\left(90^{\circ}-110^{\circ} \mathrm{E}\right.$ and $\left.10^{\circ}-0^{\circ} \mathrm{S}\right)$.

Composite analysis is used to investigate the circulation mechanisms associated with the positive and negative phases of ENSO and IOD, and also to confirm the results obtained from regression analysis. The Oceanic Niño Index (ONI) is used to identify El Niño and La Niña events from the driving GCM SST fields. ONI is defined as the 3-month running mean SST anomaly in Nino 3.4 region. The NOAA Climate Prediction Center (CPC) uses a threshold of $\pm 0.5^{\circ} \mathrm{C}$ to define ENSO phases. A year is defined as El Niño or La Niña year when ONI value is higher (lower) than $+0.5(-0.5)$ for at least five consecutive overlapping seasons, which is the average of three consecutive months of that year. Note that the anomalies are calculated relative to their climatological seasonal cycle based on the respective periods, historical (1976-2005) and far future (2070-2099).

IOD years are identified using the DMI, which is calculated as the SST anomaly difference between the western equatorial Indian Ocean $\left(50^{\circ}-70^{\circ} \mathrm{E}\right.$ and $\left.10^{\circ} \mathrm{S}-10^{\circ} \mathrm{N}\right)$ 
and south-eastern equatorial Indian Ocean $\left(90^{\circ}-110^{\circ} \mathrm{E}\right.$ and $10^{\circ}-0^{\circ} \mathrm{S}$ ). For observation and models, a threshold of $\pm 0.5^{\circ} \mathrm{C}$ is used to identify positive IOD and negative IOD years, respectively. A year is defined as positive IOD (negative IOD) year when DMI index is higher (lower) than +0.5 $(-0.5)$ for at least three consecutive overlapping seasons, defined as the average of three consecutive months of that year.

The 3-month running mean SST anomalies of ONI for observation and models for the historical (1976-2005) and future (2070-2099) are presented in Fig. 3.

\section{Results and discussions}

\subsection{Projected changes in mean rainfall}

It is important to assess the projected changes in mean rainfall over the region prior to the analysis of changes in rainfall variability associated with ENSO and IOD. To this end we analyzed the projected changes in mean rainfall as simulated by both RCMs and GCMs ensembles. Figure 1 shows the JJAS (top row), MAM (middle row) and OND (bottom row) rainfall change signal during the far future (2070-2099) under RCP8.5 relative to the reference period (1976-2005) as simulated by the ensemble mean of the GCMs and two RCMs. Statistical significance at the 5\% level was tested by applying the two-sided student's t-test. Although there is a general similarity in rainfall pattern across the CGCM and RCM simulations, noticeable disagreements exist. During JJAS, the CGCMs and RCA runs project a weak positive rainfall change signal over the central part of Ethiopia. However, this is not evident in the CCLM model, which rather shows wet anomaly in the eastern horn of Africa. Both RCM ensembles project a dry anomaly over the south-Sudan and western part of Ethiopia, whereas the GCM ensemble mean shows a weak, or even no wet signal. Another notable feature is that the RCA model projects a wet anomaly around the Victoria Lake basin and north-western parts of Sudan, but this is not seen in the CCLM and driving GCM simulations. All simulations agree in a projected decrease in rainfall over the southern and southeastern part of the region. It is important to note that JJAS is a dry season for southern and southeastern part of the region.

During the MAM season, both RCM and GCM ensemble means project wet anomalies over southeastern parts of the domain and dry anomalies over the northern parts of the domain. Both RCMs project drier conditions over the western part the region (i.e., western parts of Kenya, Rwanda, Burundi and most of Congo), whilst the GCM ensemble mean projects wetter conditions.

During OND (Fig. 1 bottom row) the GCMs and RCA ensembles show a more pronounced and widespread increase in precipitation throughout the entire region. The CCLM model, however, shows a decrease in precipitation over the northern and southern part of the domain. This contradiction may be related to the physical parametrization in CCLM (i.e not related to the resolution or the boundary forcing) as the coarse-resolution GCMs have the same signal as the RCA model. This contradiction feature between CCLM and forcing GCM is also noted in Dosio and Panitz (2016). All the models agree on the projected increase in OND rainfall over eastern horn of Africa region (Somalia, Djibouti, and eastern Ethiopia), and the changes are statistically significant at the 5\% level. The projected increase in OND rainfall over the eastern horn of Africa is similar to other studies (Shongwe et al. 2011; IPCC 2007) using CMIP3 GCMs, and (Otieno and Anyah 2013; IPCC 2013) using the latest CMIP5 models.

In general, analysis of the projected changes in the mean rainfall over the region indicates a decrease in far-future rainfall over most parts of the region during JJAS and MAM seasons, and an increase in rainfall over equatorial and southern part of the region during OND, with the largest changes in equatorial region. It is also important to note differences in rainfall projections between models where CCLM showing a general drying over the region, whereas results from the RCA4 show patterns more similar to the results of driving GCMs. We also assessed the future changes in rainfall under RCP4.5 (results not shown) and found that the results for the RCP4.5 and RCP8.5 exhibit similar patterns but the magnitudes of changes are slightly larger in the RCP8.5.

\subsection{Projected changes in the characteristics of ENSO and IOD}

\subsubsection{Changes in the mean state}

Figure 2 illustrates the changes in annual mean SST and rainfall between the future (RCP8.5) and the present climate as simulated by the ensemble mean of the driving CGCMs. As can be seen in Fig. 2 top panel, there is a clear SST warming pattern over the tropics, and an El Niñolike pattern over the tropical Pacific. A positive IOD-like warming pattern over Indian Ocean is also evident. This is consistent with other studies (e.g. Müller and Roeckner 2008) that indicated larger surface warming over central and eastern equatorial Pacific than western Pacific, and also greater surface warming over western part of Indian Ocean than the surrounding Ocean. Consistent with increased in SSTs, the western Indian and eastern and central Pacific Oceans are projected to receive more rainfall (Fig. 2 bottom), while the eastern and southern parts of the Indian Ocean, south eastern Pacific, and Atlantic Oceans are projected to receive less rainfall. A large increase in rainfall is projected over eastern and central 


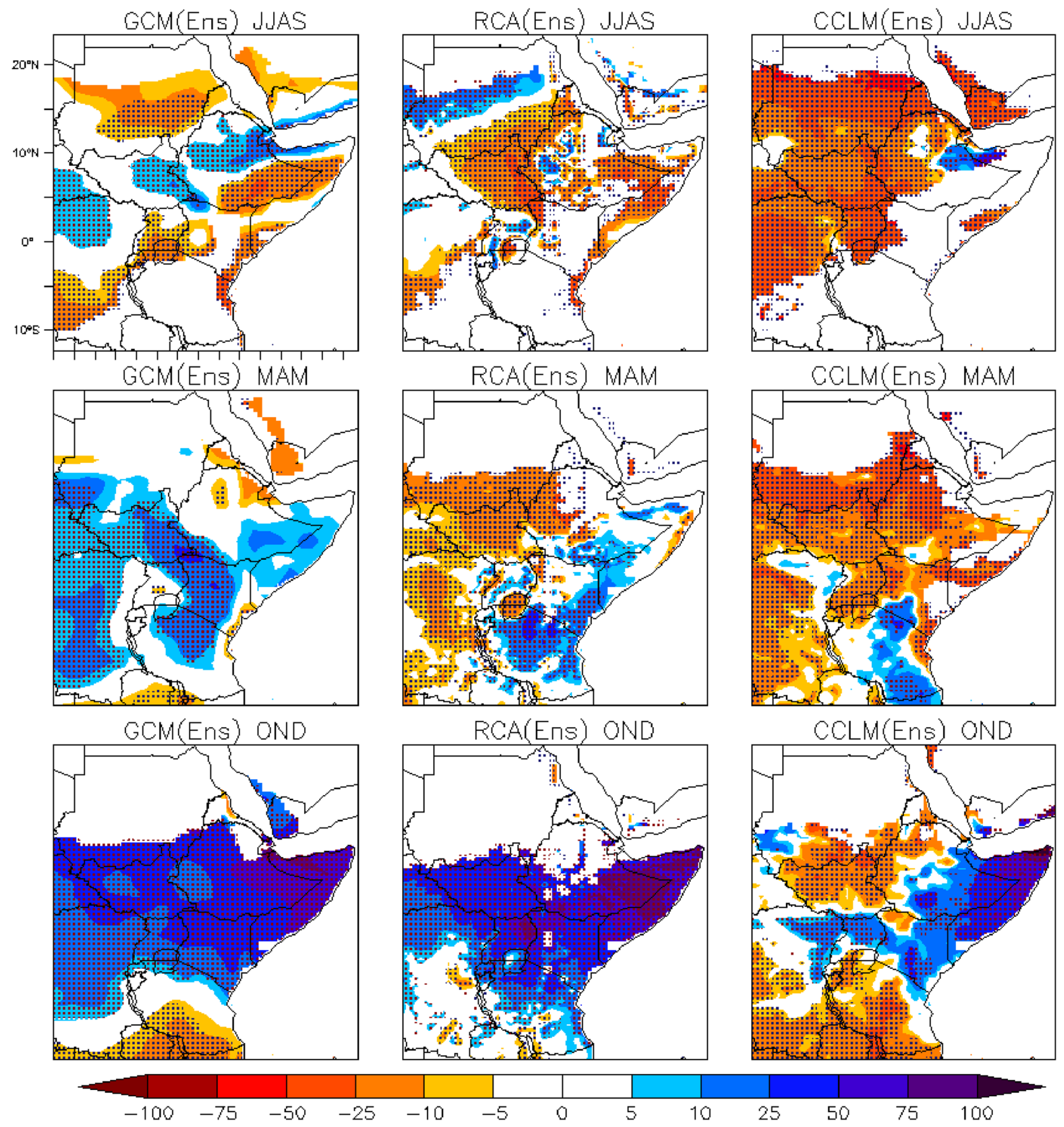

Fig. 1 Projected rainfall changes (\%) over the region during JJAS (top row), MAM (middle row) and OND (bottom row) under RCP8.5 as simulated by the ensemble mean of the RCMs and driving GCMs.

parts of Africa and most parts Asia, whereas a reduction in rainfall is projected over the southern parts of Africa and most of Europe. These results are consistent with IPCC (2013) findings. It is possible that the increase in rainfall over Eastern Africa is linked with the increase of SST
Stippling indicates regions where the change is statistically significant at the $5 \%$ level using two-sided student's t-test

over the western part of the Indian Ocean and central/ eastern Pacific Ocean. Tierney et al. (2015) noted that the increased precipitation over eastern Africa is associated with a weakening in the Walker circulation over the Indian and Pacific Ocean basins. 


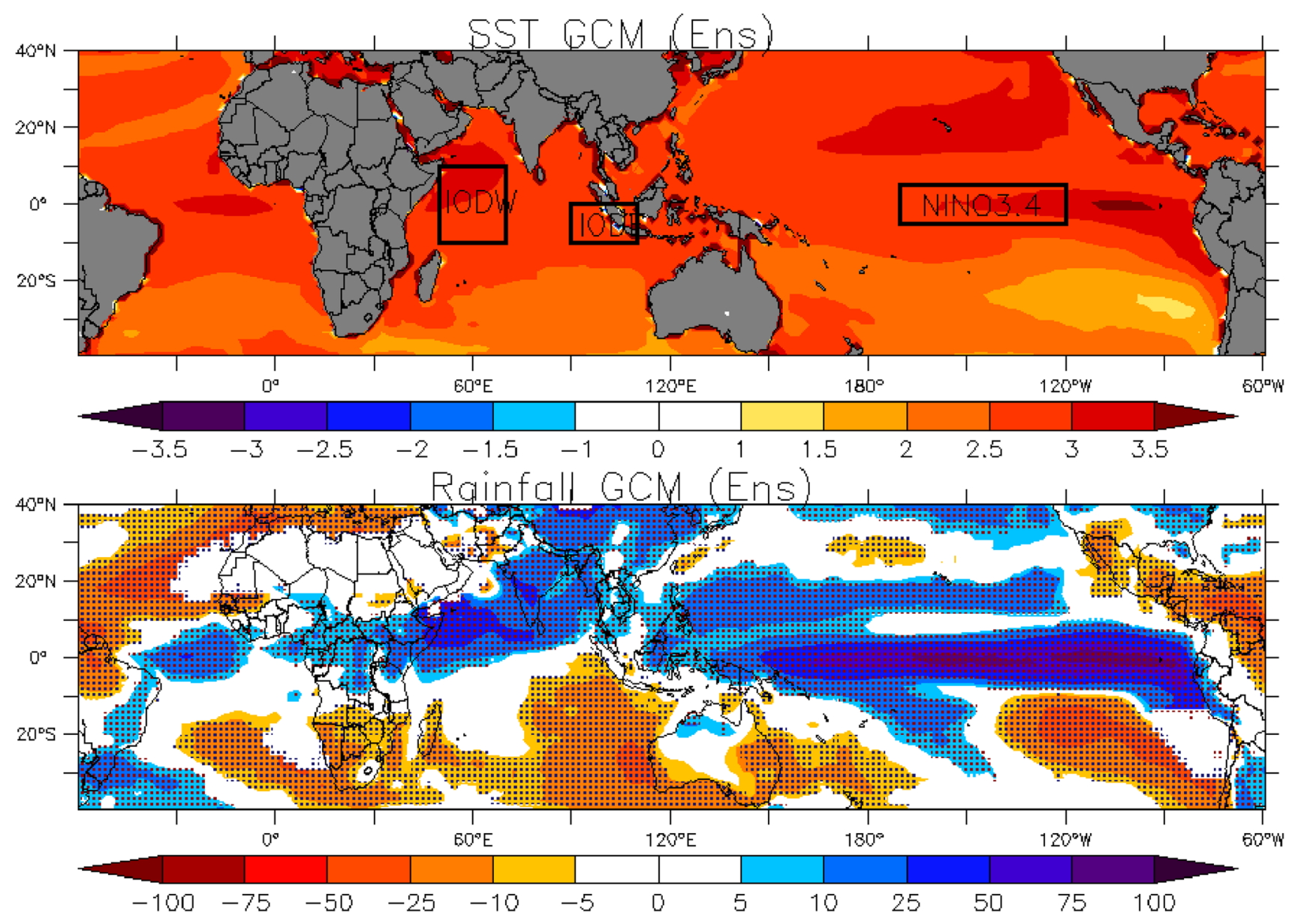

Fig. 2 Difference in mean SST $\left({ }^{\circ} \mathrm{C}\right)$ and Rainfall (\%) between the future (2070-2099) and historical (1976-2005) period from the ensemble mean of the forcing CGCMs under RCP8.5 scenario. Stip-

\subsubsection{Changes in the frequency and intensity ENSO and IOD events}

The frequency and intensity of ENSO and IOD events are analyzed for historical and future periods. The ONI and DMI are used to identify ENSO (El Niño and La Niña) and IOD (positive and negative IOD-pIOD and nIOD hereafter) events, respectively. Figure 3 shows the 3-month running mean of SST anomalies in Niño3.4 for historical (top) and future (bottom) periods. Periods of below and above normal SSTs are colored in blue and red, respectively. An El Niño or La Niña event is defined when Oceanic Nino Index (ONI) value over Niño3.4 is higher (lower) than $+0.5(-0.5)$ for at least five consecutive overlapping seasons, defined as the 3 month-running mean SST anomalies. As shown in Fig. 3, the simulated ENSO events do not synchronize with observed sequence of ENSO events. This is expected, as free-running GCMs generate their own El Niño and La Niña events.

The frequency and intensity of ENSO (El Niño and La Niña) and IOD (pIOD and nIOD) events for historical and pling in rainfall map indicates regions where the change is statistically significant at the $5 \%$ level using two-sided student's t-test

future periods are presented in Fig. 4a, b, respectively. Frequency is calculated as the number of occurrence of ENSO and IOD events, computed from the 3-month SST anomalies of ONI and DMI for historical (1976-2005) and far future (2070-2099). Thus, the larger the number indicates the more recurrent occurrence of ENSO/IOD events. To estimate ENSO intensity, we computed the average of the maximum ONI values for all El Niño and La Niña events during 1976-2005 and 2070-2099 (similar to the definition used by Zhang et al. 2012). Similarly, IOD intensities are computed as the average of the maximum DMI values for all pIOD and nIOD events. Larger absolute values represent stronger ENSO/IOD events.

For the present climate (1976-2005), 8 El Niño events with an average intensity of 1.62 and 7 La Niña events with an average intensity of 1.52 are present in the observations (ERSST.v3b, Smith et al. 2008), whereas no GCM shows the same number of El Niño and La Niña as observed. Half of the models overestimate the frequency of El Niño and La Niña events. In particular, CNRM-CM5 

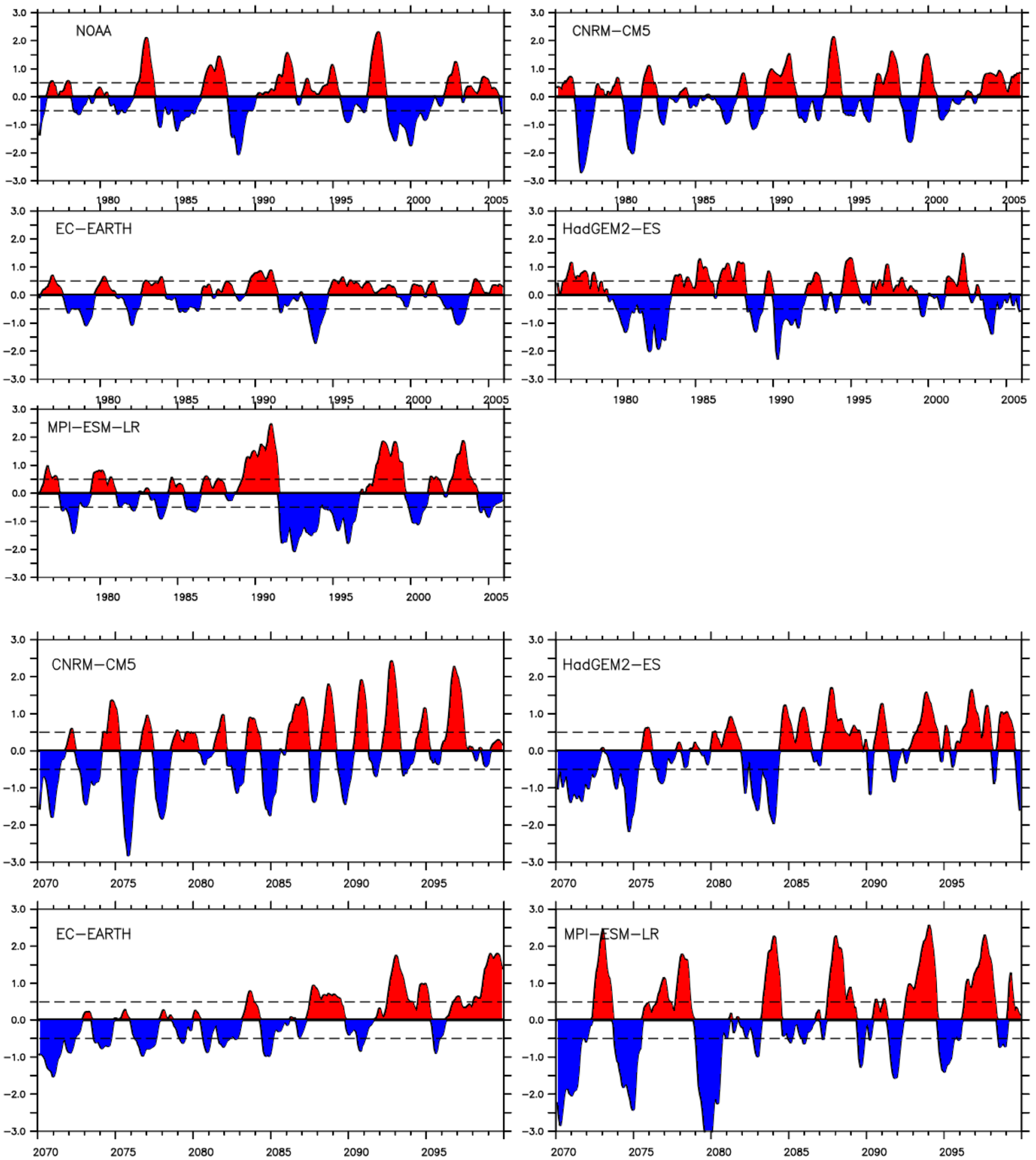

Fig. 3 3-month running mean of SST anomalies in Nino3.4 region for the historical (1976-2005) [top] and future (2070-2099) [bottom] periods. Dashed lines represent the $\pm 0.5^{\circ} \mathrm{C}$ threshold lines

and HadGEM2-ES overestimate the frequency of El Niño producing 10 and $11 \mathrm{El}$ Niño events in 30 years period, whereas MPI-ESM-LR underestimates the frequency of El Niño, but overestimates the frequency of La Niña.
EC-EARTH model underestimate both the frequency of El Niño and La Niña events, with only one El Niño event in 30 years. In terms of the intensity, most models underestimate the intensity of El Niño and La Niña events, 

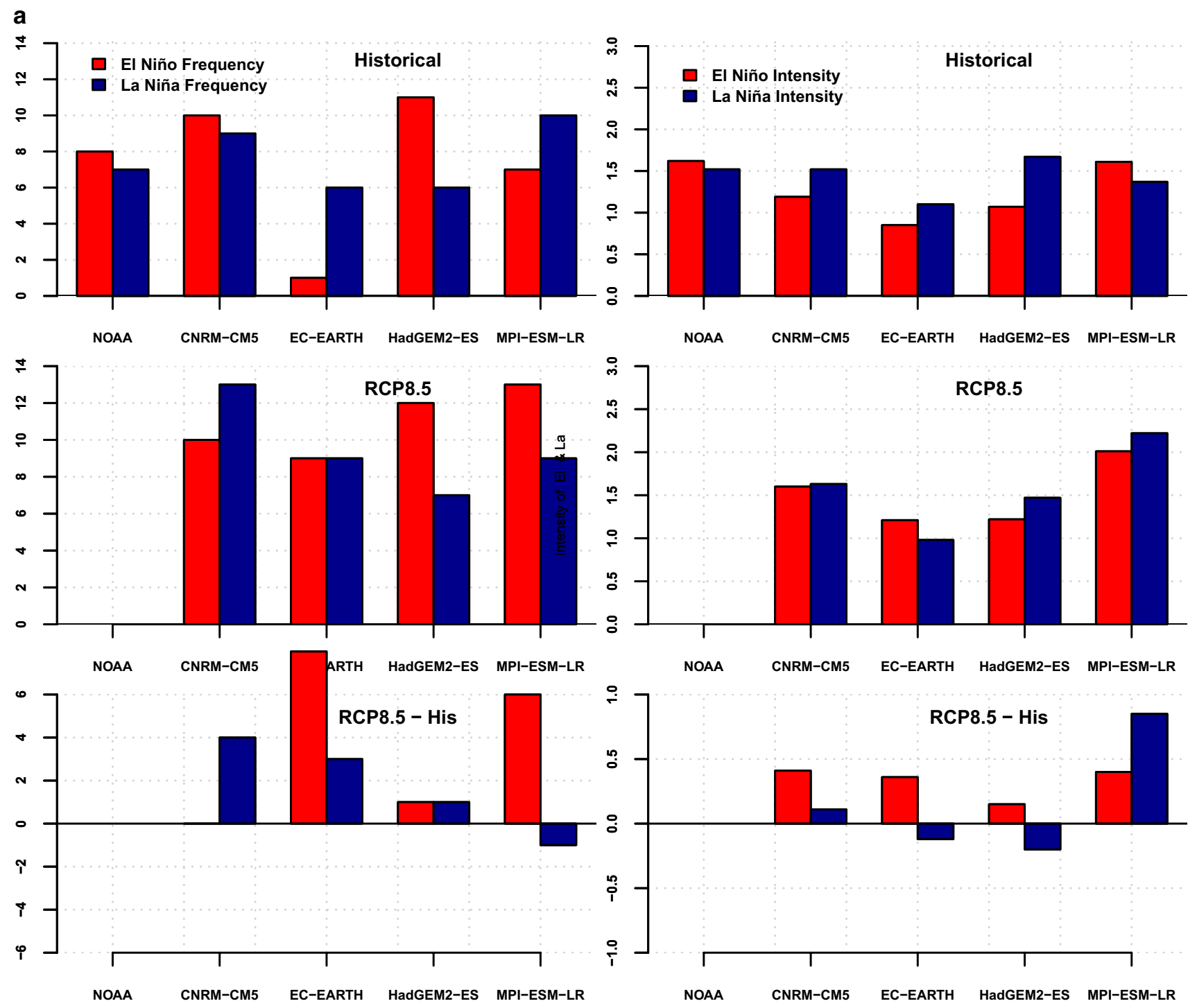

Fig. 4 a Frequency (left) and intensity of ENSO (right) events for the historical period (1976-2005) [1st row], future (2070-2099) under RCP8.5 scenario [2nd row] and changes in the future relative to the historical period (3rd row). b Frequency (left) and intensity of IOD

(right) events for the historical period (1976-2005) [1st row], future (2070-2099) under RCP8.5 scenario [2nd row] and changes in the future relative to the historical period (3rd row)

with only one model (CNRM-CM5) reproducing the same intensity as observed.

For IOD, three pIOD events with average intensity of 0.89 and four nIOD events with average intensity of 0.61 are reported in ERSST.v3b for the period of 1976-2005. It is worth mentioning that the number of pIOD and nIOD events identified in this analysis does not agree with that of Endris et al. (2016), who reported four pIOD and seven nIOD events for the period of 1982-2005 using the NOAA Optimum Interpolation (OI) Sea Surface Temperature (SST) V2 (NOAA_OI_SST_V2) available at one degree resolution. This discrepancy is due to the use of a different SST dataset. Taking ERSST.v3b as a reference, it appears that

all the models overestimate the frequency and intensity of pIOD and nIOD events, except HadGEM2-ES, which shows the same intensity of pIOD as observed. Although, the two datasets disagree in producing the frequency and intensity of IOD events, the frequencies and intensities of ENSO events obtained from the two datasets are similar for the same period.

For the future climate (2070-2099), there is no clear indication that the frequencies and intensities of ENSO and IOD will increase or decrease. As is evident in Fig. 4a, b, some of the models project an increase of ENSO and IOD events, whilst others a decrease. Under the RCP8.5 scenario, all the models agree that there will be an increase in the 

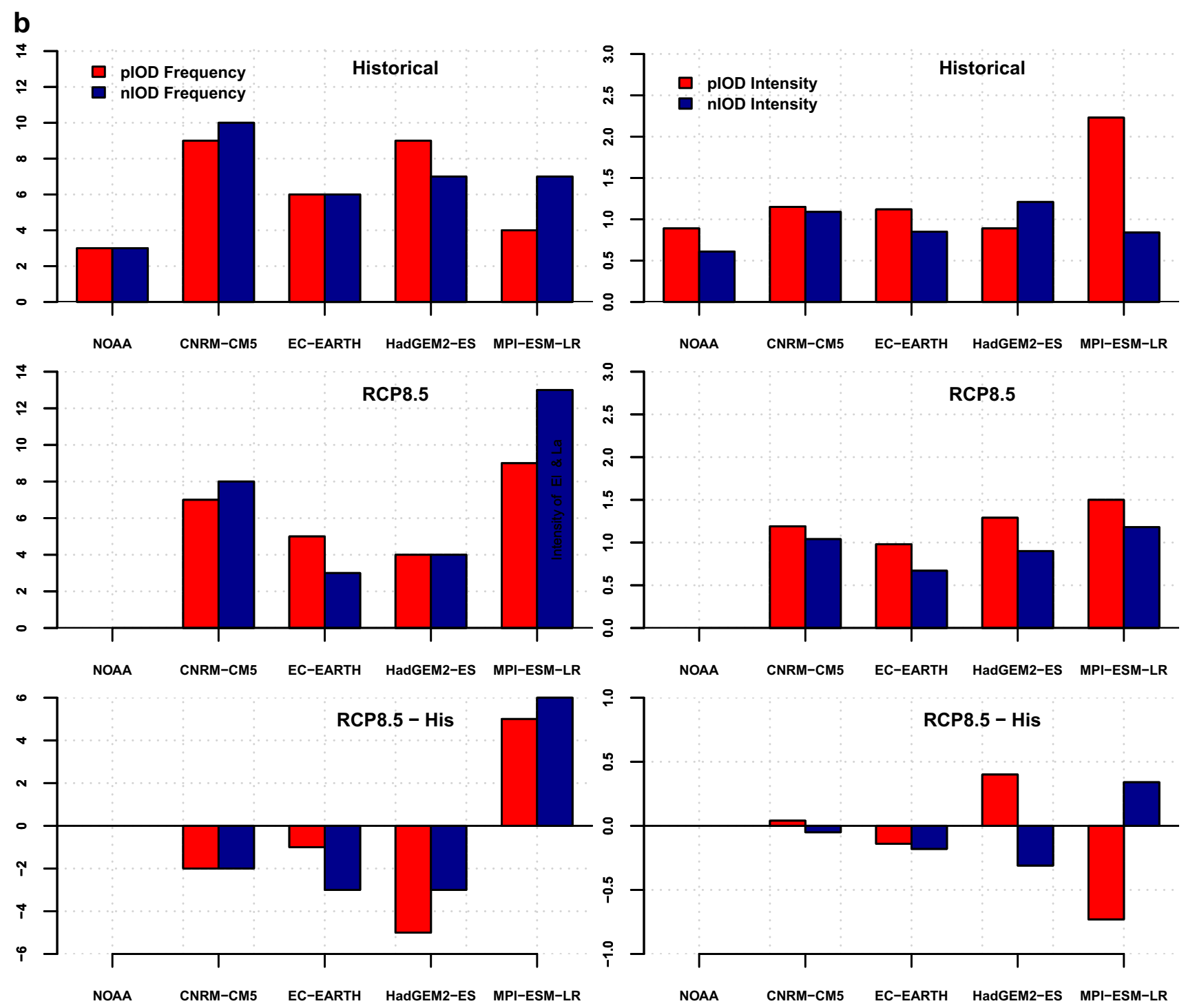

Fig. 4 (continued)

intensity of El Niño, and three of the four models project an increase in its frequency (Fig. 4a). This is consistent with SST warming in eastern tropical Pacific that the GCMs project more El Niño events in the far future compared to the present. In the case of the IOD there is no clear signal either in the frequency or intensity of IOD events in future. Almost half of the models project an increase and half the models a decrease (Fig. 4b).

In general, the above analyses suggest that future changes in ENSO and IOD frequency and intensity are model dependent, as also reported by Stevenson et al. (2012) and Steinhoff et al. (2015). Despite the agreement in increase in the frequency and intensity of El Niño under RCP8.5, there is no consensus among the models on future changes to ENSO (El Niño and La Niña) and IOD (pIOD and nIOD) intensity and frequency.

\subsection{Teleconnection patterns in present and future period associated with ENSO and IOD}

\subsubsection{Rainfall patterns associated with ENSO and IOD}

Endris et al. (2016) have examined the ability of regional and global models to reproduce historical teleconnection patterns over Eastern Africa. In this analysis, we used the same GCMs and RCMs to analyses the future teleconnection patterns. Results of the historical simulations are also assessed for the purpose of interpretation future teleconnection patterns. The analysis focuses on the rainfall seasons-JJAS, MAM and OND. Figure 5 shows the rainfall teleconnection for the JJAS season against the Niño3.4 index in the historical (1976-2005), and future (2070-2099) periods as estimated by linear regression. The top row shows 

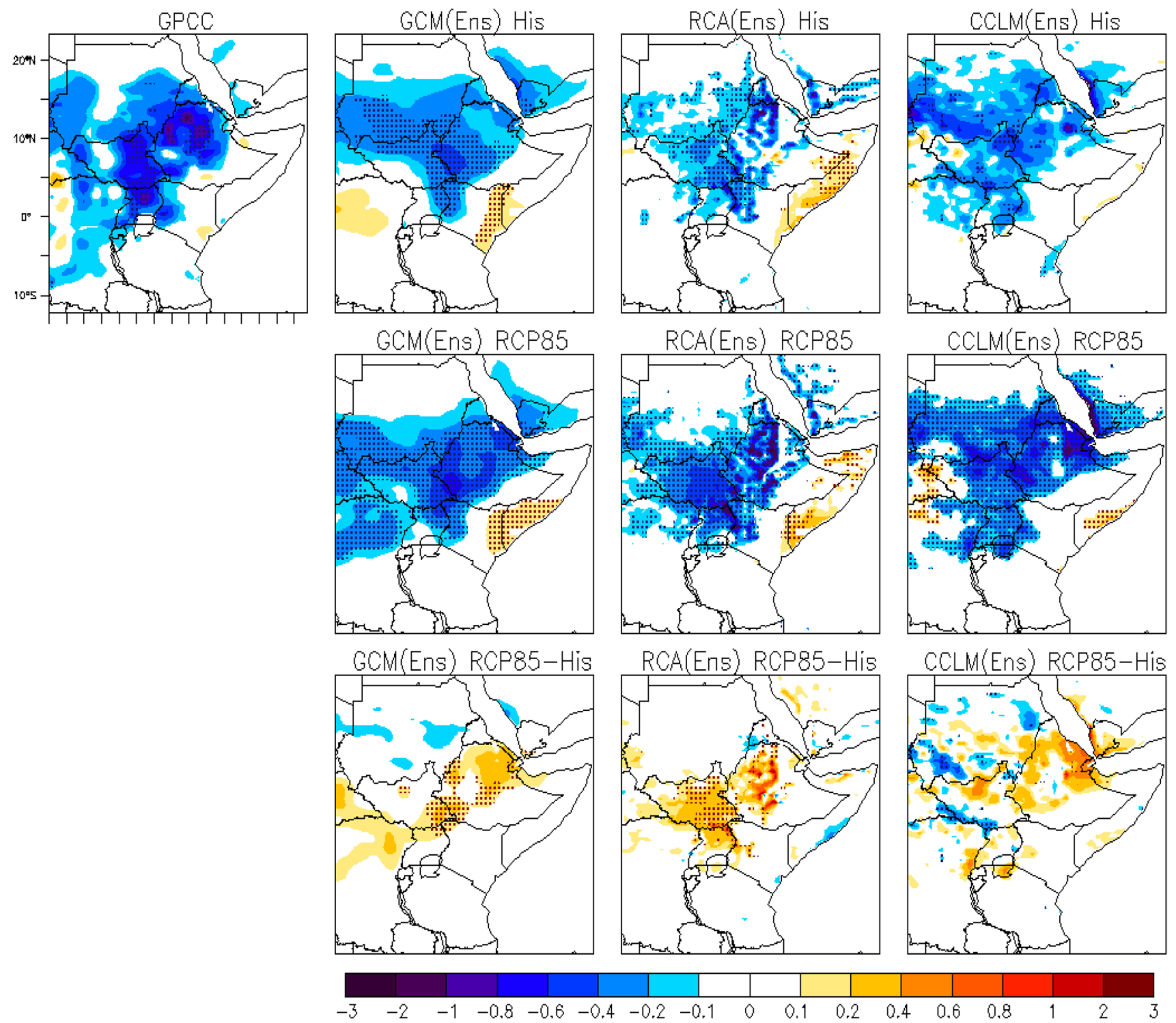

Fig. 5 JJAS teleconnections computed using linear regression against NINO3.4 index for historical (1976-2005) and future (2070-2099) periods. The first row indicates the historical teleconnection patterns from observation, global ensemble mean, and corresponding downscaled regional ensemble means. The second row shows the future

the results from observation, GCMs, and the corresponding downscaled ensemble means in the historical period. The second row represents the projected teleconnection under the RCP8.5 scenario. The third row indicates differences in teleconnection patterns between future and historical period. In the present climate, negative coefficients are observed over the northern part of the domain (top row), which demonstrates the negative association between tropical Pacific SST and summer (JJAS) rainfall. Warm (cold) SSTs over the tropical Pacific Ocean leads to a dry (wet) summer in the northern part of eastern Africa. Looking at the teleconnection patterns in the historical period (Fig. 5, first row), teleconnection patterns under RCP8.5 scenario. The third row shows differences in teleconnection patterns between future and historical period. Units are $\mathrm{mm} / \mathrm{day} / \mathrm{deg}{ }^{\circ} \mathrm{C}$. Stippling indicates regions where the regression coefficient is statistically significant at the 5\% level

both the global and regional ensembles correctly represent the negative relationship between ENSO and rainfall over northern part of the region.

On the basis of the results from the historical run, we further examine teleconnection patterns under the future climate scenario. The spatial patterns of teleconnections in future period are similar to those in the historical period (Fig. 5, second row), with negative coefficients over the northern part of the domain still present in both global and regional simulations. This suggests that the present spatial pattern of the teleconnections will persist under future global warming. However, the degree/magnitude of the relationship 
differs compared to the historical period. This is consistent with the in differences in rainfall teleconnection patterns between future and historical period (Fig. 5 3rd row). Teleconnection changes/differences are computed based on the difference in teleconnection patterns between the future (2070-2099) and historical (1976-2005) period (i.e. taking their absolute values). By looking at the difference in teleconnection patterns, we can deduce the strength of the teleconnection. It can be seen that a positive anomalies dominate over the northern part of the domain, indicating a strengthening of the teleconnection between ENSO and JJAS rainfall in the future compared to the present.
We further investigate the future changes in teleconnection patterns using the composite analysis to confirm the results and to reveal some important information that was not shown by the regression analysis (see Fig S1). Like the regression analysis, the composite analysis shows an enhancement of ENSO and summer rainfall relationship in future compared to the present period; however, this enhancement was associated with La Niña events only. The magnitude of rainfall anomalies associated with El Niño years is likely to be reduced in the future. This supports the idea of a non-linear, rather than symmetrical, association between ENSO and Eastern Africa rainfall.
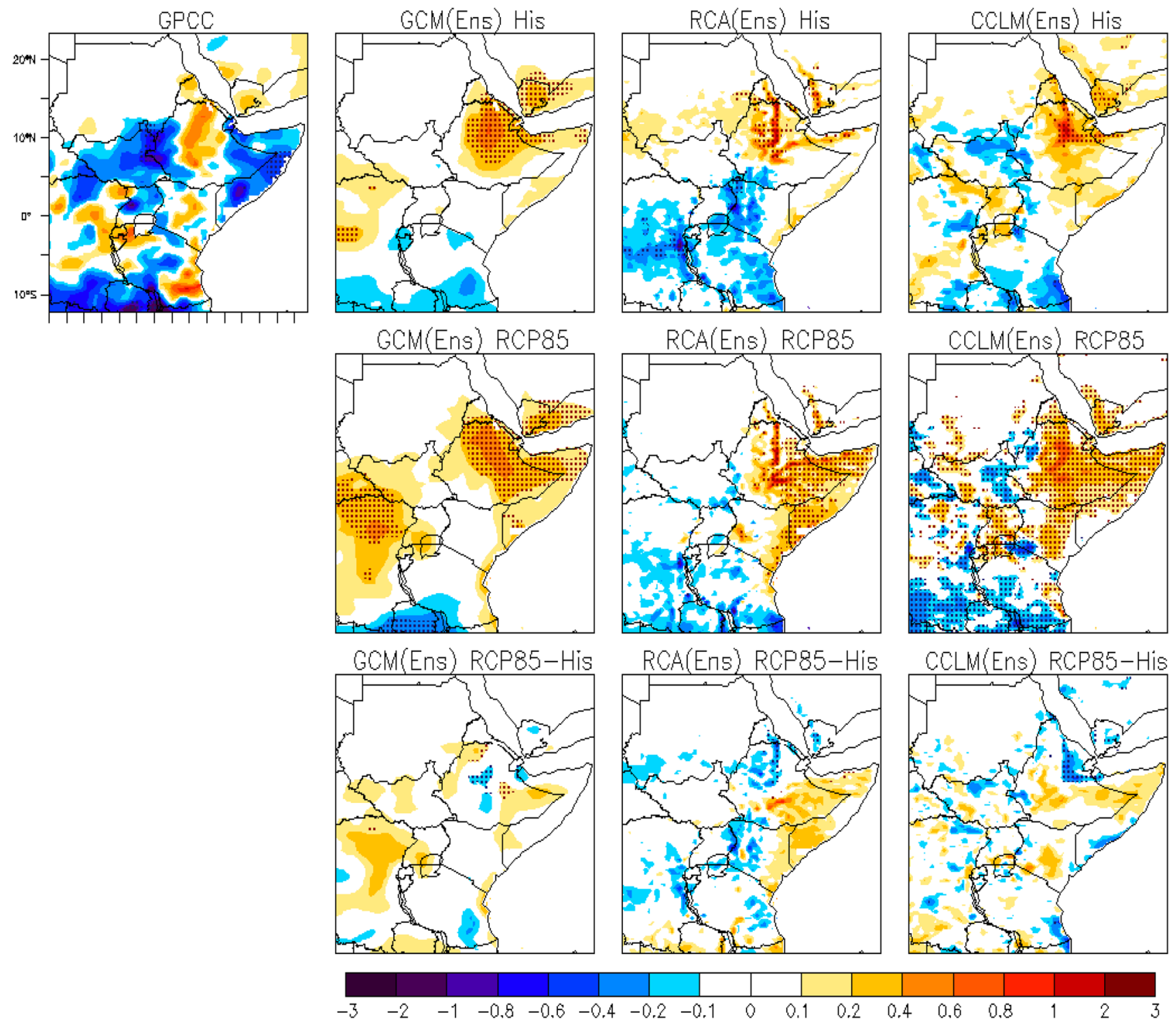

Fig. 6 MAM teleconnections computed using linear regression against NINO3.4 index for historical (1976-2005) and future (20702099) periods. The first row indicates the historical teleconnection patterns from observation, global ensemble mean, and corresponding downscaled regional ensemble means. The second row shows the future teleconnection patterns under RCP8.5 scenario. The third row shows differences in teleconnection patterns between future and historical period. Units are $\mathrm{mm} / \mathrm{day} / \mathrm{deg}{ }^{\circ} \mathrm{C}$. Stippling indicates regions where the regression coefficient is statistically significant at the $5 \%$ level 
Although the long rains (MAM) produce more rainfall than the short rains (OND) over the region, the former are generally less variable (Nicholson 2017 and references therein), and weakly correlated with oceanic and atmospheric features (e.g., Ogallo et al. 1988; Hastenrath et al. 1993; Rowell et al. 1994; Philipps and McIntyre 2000). Moreover, previous studies have shown an intraseasonal contrast or inhomogeneity within the season. For example, Camberlin and Philippon (2002a, b) show that spatial rainfall anomaly patterns are similar in March and April but quite different in May. Studies by Rowell et al. (1995); Nicholson and Kim (1997) and Indeje et al. (2000) also found that time series of interannual variability for the months of March, April, and May are different. Due to this inhomogeneity within the season, some studies suggest that subseasonal analysis is required for MAM season to advance the understanding and prediction of precipitation variability (e.g. Camberlin et al. 2009a, b, 2010; Moron et al. 2013; Rowell et al. 1994; Mutai and Ward 2000). On the other hand, some studies (e.g., Williams and Funk 2011; Lyon and DeWitt 2012; Lyon et al. 2014; Hoell and Funk 2014; Funk et al. 2014; Vigaud et al. 2017) have indicated that there is strong
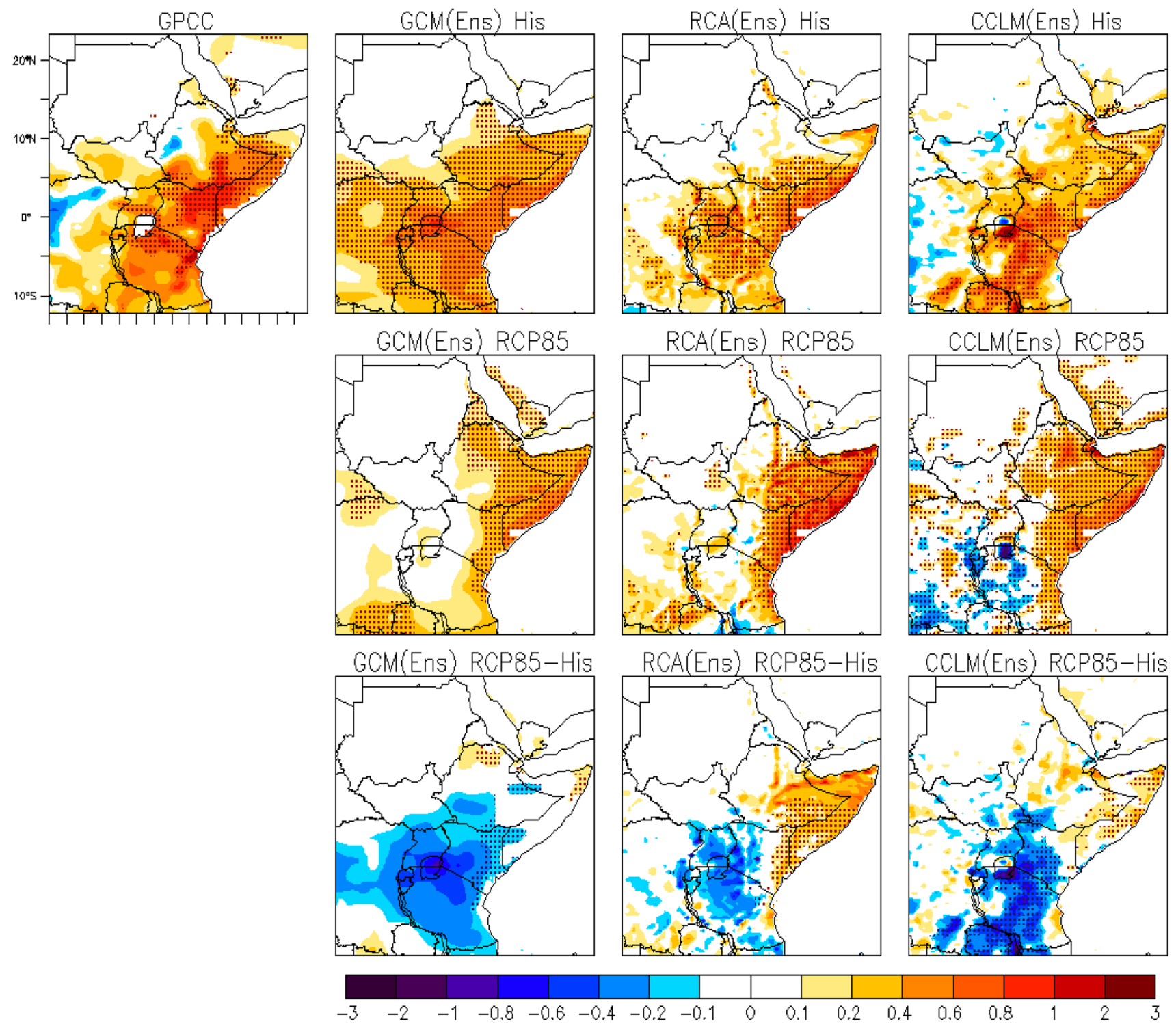

Fig. 7 OND teleconnections computed using linear regression against NINO3.4 index for historical (1976-2005) and future (2070-2099) periods. The first row indicates the historical teleconnection patterns from observation, global ensemble mean, and corresponding downscaled regional ensemble means. The second row shows the future teleconnection patterns under RCP8.5 scenario. The third row shows differences in teleconnection patterns between future and historical period. Units are $\mathrm{mm} / \mathrm{day} / \mathrm{deg}{ }^{\circ} \mathrm{C}$. Stippling indicates regions where the regression coefficient is statistically significant at the $5 \%$ level 
teleconnection between Indo-Pacific SSTs and East African MAM rainfall in recent years. Their analyses show that the post 1999 droughts (2000, and 2008, 2009, 2011 and 2017), which resulted in abrupt decline in MAM rainfall in the region, are strongly linked with Indo-Pacific SSTs changes.

Here we present the associations between Niño3.4 and MAM rainfall for present and future periods as well as differences in teleconnection patterns between future and historical period (Fig. 6). The aim is to assess the observed and modelled teleconnection patterns for present climate and investigate the future teleconnection patterns in warmer climate. In the present period, there is little association with Niño3.4 (Fig. 6, first row). Moreover,
Fig. 9 JJAS El Niño (top) and La Niña (bottom) composite map of SLP (shaded in $\mathrm{hPa}$ ) and $850 \mathrm{hPa}$ wind (vectors in $\mathrm{m} / \mathrm{s}$ ) for historical (1976-2005) [1st row], future (2070-2099) [2nd row] and differences in between future and historical period (3rd row)

the modelled teleconnection patterns are not consistent with the observed ones. For example, the observations show negative association between Niño3.4 and MAM rainfall over Eastern horn of Africa, whereas the simulations show positive relationship. In the future (Fig. 6 second row), the models show stronger positive association between Niño3.4 and MAM rainfall over the Eastern
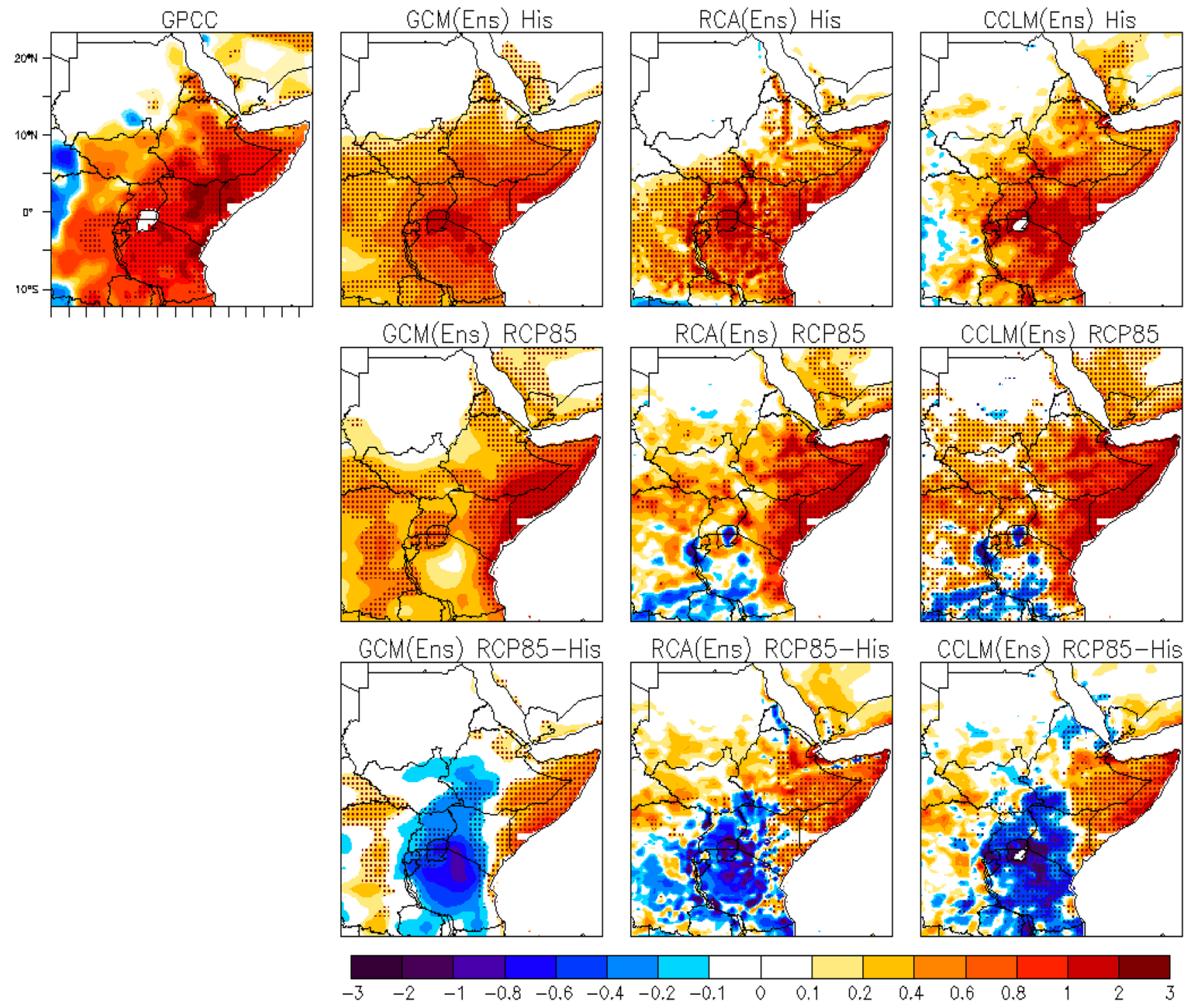

Fig. 8 OND teleconnections computed using linear regression against DMI index for historical (1976-2005) and future (2070-2099) periods. The first row indicates the historical teleconnection patterns from observation, global ensemble mean, and corresponding downscaled regional ensemble means. The second row shows the future telecon- nection patterns under RCP8.5 scenario. The third row shows differences in teleconnection patterns between future and historical period. Units are $\mathrm{mm} / \mathrm{day} / \mathrm{deg}{ }^{\circ} \mathrm{C}$. Stippling indicates regions where the regression coefficient is statistically significant at the $5 \%$ level 

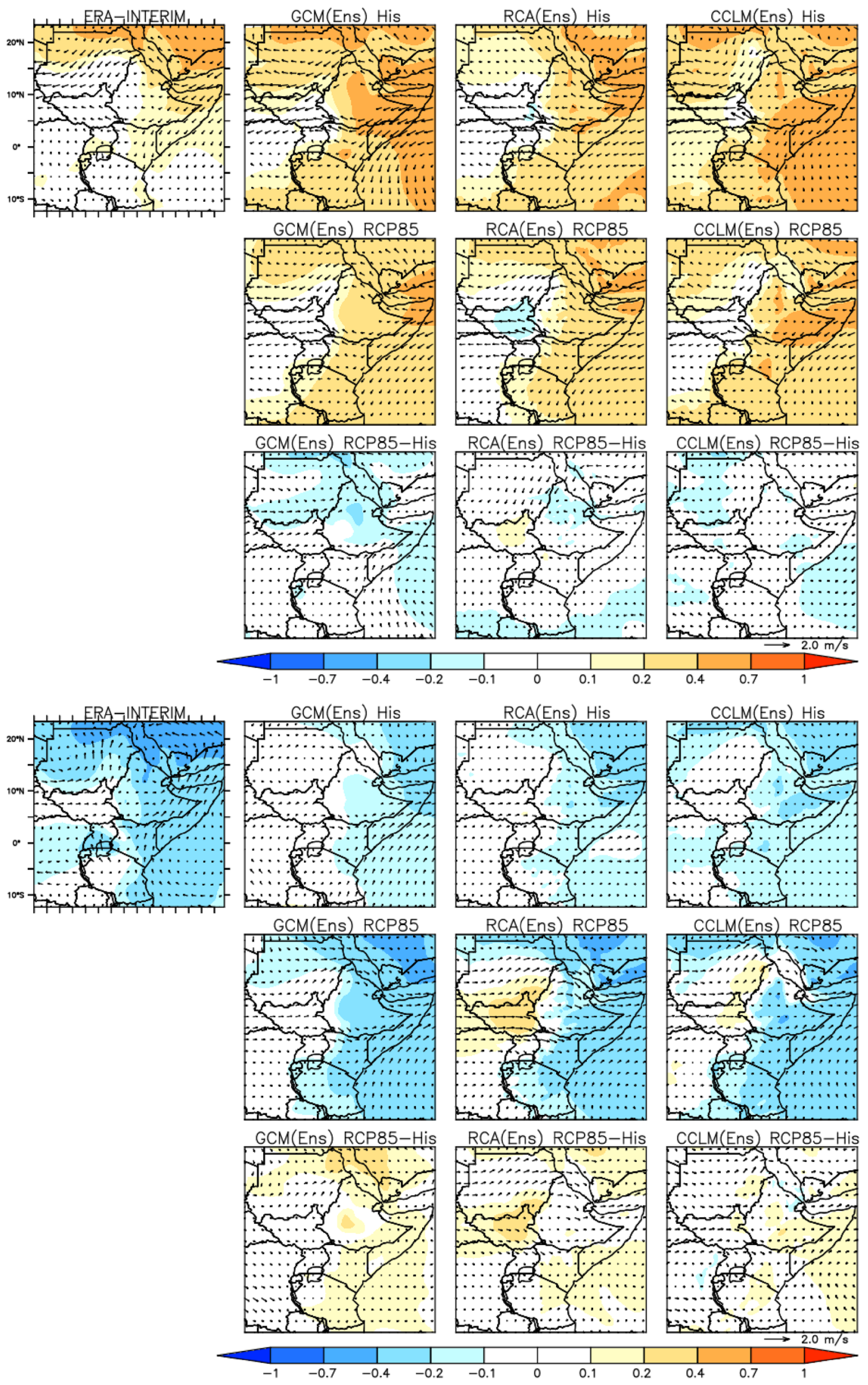
horn of Africa. This might be due the fact that observed El Niño teleconnections are becoming stronger in recent years as shown by the above-mentioned studies. Recent studies by Liebmann et al. $(2014,2017)$ also revealed the observed increasing correlation strength in recent years concomitant with a strengthening of the Indian Ocean branch of the Walker circulation. The explanation to this is that the observed warming over Indo-Pacific warm pool has enhanced convection over Indonesia and strengthened the Indian Ocean upper-level easterlies coming from the convective area, which result in anomalous upper level convergence and suppressed rainfall over the horn of Africa (Yang et al. 2015; Liebmann et al. 2017). The lack of any significant relationships between ENSO and longrains in our analysis for historical period is in agreement with earlier studies (e.g., Ogallo et al. 1988; Hastenrath et al. 1993; Rowell et al. 1994; Philipps and McIntyre 2000), but not with more recent studies (e.g., Williams and Funk 2011; Lyon et al. 2014; Hoell and Funk 2014; Funk et al. 2014; Yang et al. 2015 and; Liebmann et al. 2017); this discrepancy could be due the choice of the historical period (1976-2005), which does not cover the recent drought years.

Our study further analyzed the MAM rainfall teleconnections associated with IOD (Figure not shown). The results show that there are weak teleconnections and large discrepancies between observed and simulated teleconnection patterns in historical period, and also no significant changes in future. The weak relationship between IOD and the long-rains in the historical and future periods might be due to the fact that IOD events tend to be at maturity phase during November-December-January (NDJ) period and at the onset and decay phases during MAM, so that there will likely be a weak linkage between IOD and MAM rainfall. The other possible reason for the weak teleconnection during MAM season might be the inhomogeneity of interannual variability between the months and rainfall teleconnections are also very different in each month and the net impact tends to be insignificant as suggested by previous studies (Nicholson and Kim 1997; Camberlin and Philippon 2002a, b; Zorita and Tilya 2002). Rainfall teleconnections for each month has not been investigated here as it is beyond the scope of this study.

It is widely established that rainfall anomaly during short rain season (OND) is associated with both ENSO and IOD (e.g., Hastenrath 2007; Bahaga et al. 2015; Endris et al. 2016). As such, our analysis assesses both the influence of ENSO and IOD during OND season. Figures 7 and 8 show the OND rainfall telconnection against Niño3.4 and DMI for the historical and future periods, respectively, in which Niño3.4 is the measure strength or phase of ENSO and DMI is the measure of the strength or phase of IOD. Both the positive phases of ENSO and IOD are associated
Fig. 10 MAM El Niño (top) and La Niña (bottom) composite map of SLP (shaded in hPa) and $850 \mathrm{hPa}$ wind (vectors in $\mathrm{m} / \mathrm{s}$ ) for historical (1976-2005) [1st row], future (2070-2099) [2nd row] and differences in between future and historical period (3rd row)

with above normal rainfall over the region. Conversely, the negative phases of ENSO and IOD are associated with below normal rainfall. It is notable that IOD-rainfall teleconnection patterns are more robust than the ENSO-rainfall teleconnection patterns, which is in agreement with previous studies (e.g Black 2005; Behera et al. 2005; Bahaga et al. 2015). It can be seen that both the global and regional simulations robustly reproduce the positive relationship between the ENSO and IOD, and OND rainfall in the present climate (see Figs. 7, 8 1st rows). In the future (second row), the positive association between ENSO/IOD and OND rainfall over the equatorial part of the Eastern Africa is preserved. However, the positive association over the southern part of Eastern Africa is reversed to be negative association. This feature is particularly noticeable in differences in rainfall teleconnection patterns between the future and historical periods (Figs. 7, 8 third rows).

In Fig. 7, the third row shows differences in teleconnection patterns between future and historical period associated with ENSO. Results indicate that there is a dipole change signal, i.e. a positive change over the eastern horn of Africa (Somalia, South-eastern part of Ethiopia and eastern part of Kenya), and a negative change over the southern parts of eastern Africa (over most part Tanzania, Kenya and Uganda). This implies that the link between ENSO and rainfall over eastern horn of Africa becomes stronger in the future compared to the present climate. Conversely, the link will become weaker over the southern part of the region. There are however slight differences in the magnitude of teleconnection patterns between the GCM ensemble and RCM ensembles. Positive change over the eastern horn of Africa is not visible in the GCM ensemble despite the presence of some spots of positive values.

The differences in OND rainfall teleconnection patterns between the future and historical experiments associated with IOD are presented in Fig. 8 third row. The changes in teleconnection patterns are similar to those of the ENSO patterns, despite the changes associated with IOD are stronger and emerging compared to ENSO. Strengthening of IOD relationship is identified over the East horn of Africa, while weakening of IOD relationship is observed over the South Eastern part of the region.

We further performed a composite analysis associated with ENSO and IOD to verify the results obtained from regression analysis (see supplemental Fig. S2 and S3). The results obtained from composite analysis are consistent with those of the regression map. The strengthening (weakening) in relationship between ENSO/IOD and OND rainfall 

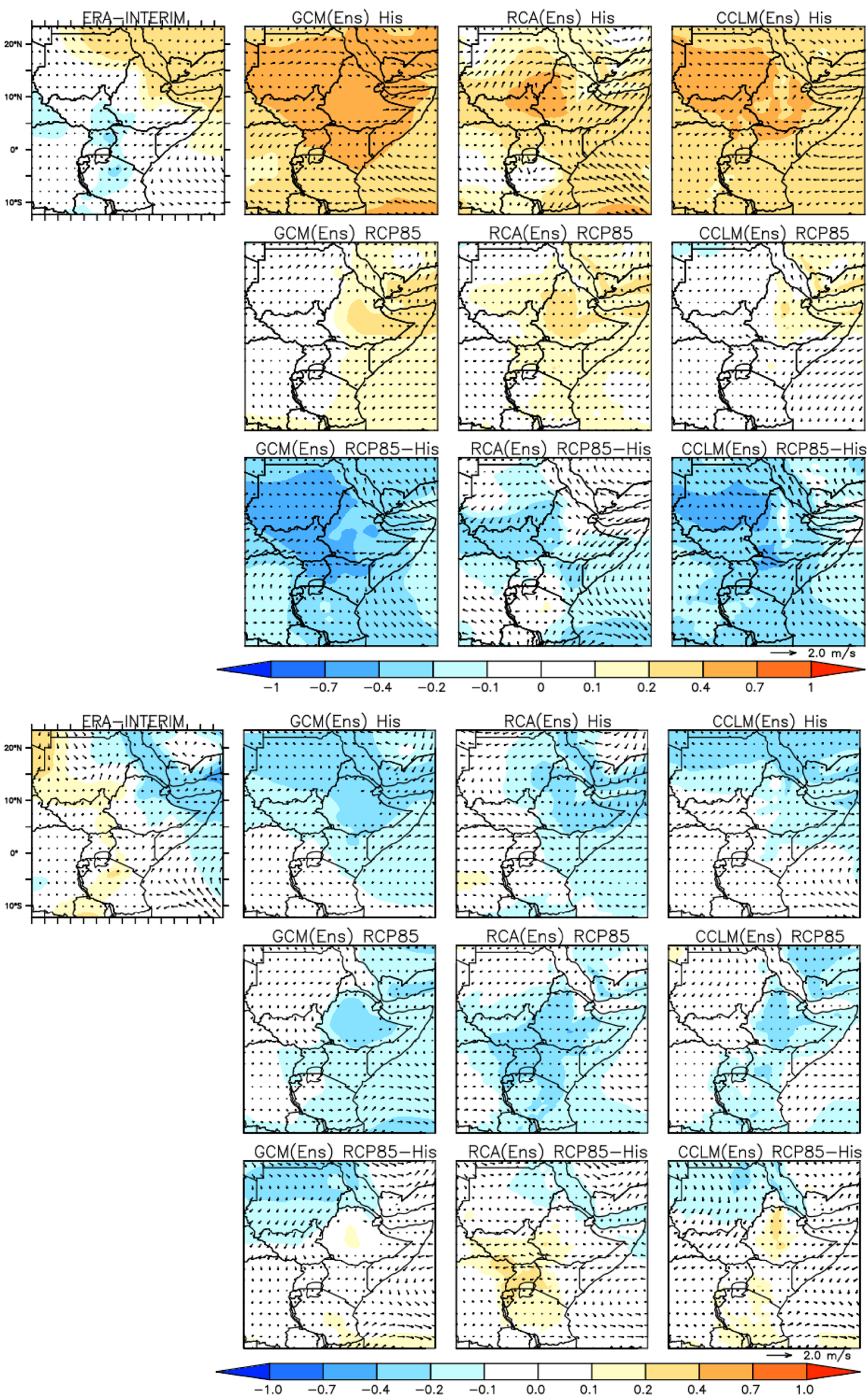
over east horn of (south Eastern) Africa are still persistent in composite results. It is expected that these features might be linked to changes to the mean state, or to a shift in the balance competing feedback processes. A thorough investigation of feedback processes was not possible here; however, mean state metrics presented in Fig. 3 indicate an El Niñolike (positive IOD-like) warming pattern over the tropical Pacific (Indian) Ocean. Thus, the enhanced rainfall over the East horn of Africa might be partly linked with enhanced warming in the western part of the Indian Ocean, which also has a link with warming in the eastern part of the Pacific Ocean. A recent study by Souverijns et al. (2016) attributed the increase in precipitation over Eastern horn of Africa to an enhancement of water vapor content in a warmer world and an increased moisture transport from easterlies.

\subsubsection{Circulation patterns associated with ENSO and IOD}

To understand the circulation mechanisms associated with the dry and wet years, composite maps of different parameters for positive and negative ENSO/IOD events have been analyzed. Different studies have shown that rainfall over Eastern Africa is strongly associated with both low-level and upper level wind circulation. In particular, the low level winds are very important for low-level moisture advection (Lyon 2014). Also the surface pressure directly relates to the mass of air in a vertical column above the surface and gives a measure of the total atmospheric mass distribution. For this reason, we have analyzed the $850 \mathrm{hPa}$ wind and the air pressure at sea level (SLP).

Figure 9 shows the composite of JJAS sea level pressure and low-level wind $(850 \mathrm{hPa})$ anomalies during El Niño (top panel) and La Niña (bottom panel) events from the ERAInterim reanalysis, regional and global simulations for the historical (first rows), future periods (second row) and difference between the future and the historical period (third row). The El Niño and La Niña composites of multimodel ensemble mean are created from the composites of Individual models (i.e. the single model composite is calculated first). During El Niño years, strong positive SLP anomalies are observed over the domain, extending from the Arabian Peninsula towards the Greater Horn of Africa. The presence of this positive anomaly suggests the existence of anticyclonic activity (descending air) that leads to a reduction of rainfall over the region. It is also indicative of a clear a reduction of westerly and southwesterly winds from the Gulf of Guinea, and the Somali Low Level Jets (SLLJ) from the Mascarene high. These are the main sources of moisture over the northern part of the domain during JJAS. The reduction of these winds is demonstrated by the presence of easterly wind anomaly vectors over western part of Eastern Africa and northeasterly wind anomaly vectors off the coast of East Africa. Conversely, the composite for La Niña
Fig. 11 OND El Niño (top) and La Niña (bottom) composite map of SLP (shaded in $\mathrm{hPa}$ ) and $850 \mathrm{hPa}$ wind (vectors in $\mathrm{m} / \mathrm{s}$ ) for historical (1976-2005) [1st row], future (2070-2099) [2nd row] and differences in between future and historical period (3rd row)

events shows opposite patterns (i.e., negative SLP anomalies over the Arabian Peninsula extended down to the region), which reflects the deepening of the monsoon trough over the Arabian Peninsula. The deeper monsoon trough over the Arabian Peninsula is strongly associated with greater rainfall over the eastern Africa during JJAS (Diro et al. 2011; Endris et al. 2016). Nicholson (2017) also stated that lowlevel cyclonic flow over the Arabian Peninsula provides ascent over the Yemen Highlands and northeastern Ethiopia, and is critical in the development of westward propagating convective systems that characterize the peak of the rainy season. During La Niña an increase low-level Somali jets (LLSJ) anomalies is clear. There is also a marked increase in the strength of westerly wind anomalies from the Gulf of Guinea and southwesterly wind anomalies from Congo rainforest basin, resulting in more moisture being advected to the region. There is a fairly good agreement between the reanalysis, and the regional and global ensemble means in reproducing the anomalous circulations patterns associated with El Niño and La Niña events in the historical period. The anomalous circulation patterns in the future are similar to the historical patterns (Fig. 9 second row). However, it appears that there is an intensification of the low-level Somali jets (LLSJ) and westerly wind anomalies associated with La Niña years in future, compared to the historical pattern. In regional simulations, positive SLP anomalies are noted over western part of the domain (Sudan and South Sudan), which are not present in the GCM simulation. Differences in SLP and $850 \mathrm{hPa}$ wind anomalies associated with El Niño and La Niña between the future and the historical period are shown in Fig. 9 third rows (top panel for El Niño and bottom panel for La Niña). As for rainfall, the difference in SLP anomalies associated with El Niño and La Niña between the future and historical period are computed by taking their absolute values. Consistent with the rainfall increase, there is an intensification of the low-level Somali jets (LLSJ) and westerly wind anomalies associated with La Niña years in future compared to the historical pattern (Fig. 9 bottom panel). This is the likely driver of the increased rainfall anomalies associated with La Niña events in future compared to the historical period. It is also evident that the deeper the monsoon trough over the Arabian Peninsula is associated with greater rainfall over the northern part of the region during JJAS.

Composite anomalies of SLP and $850 \mathrm{hPa}$ wind associated with El Niño and La Niña during MAM season are shown in Fig. 10. As for the MAM rainfall, discrepancies in circulations anomalies associated with ENSO events 

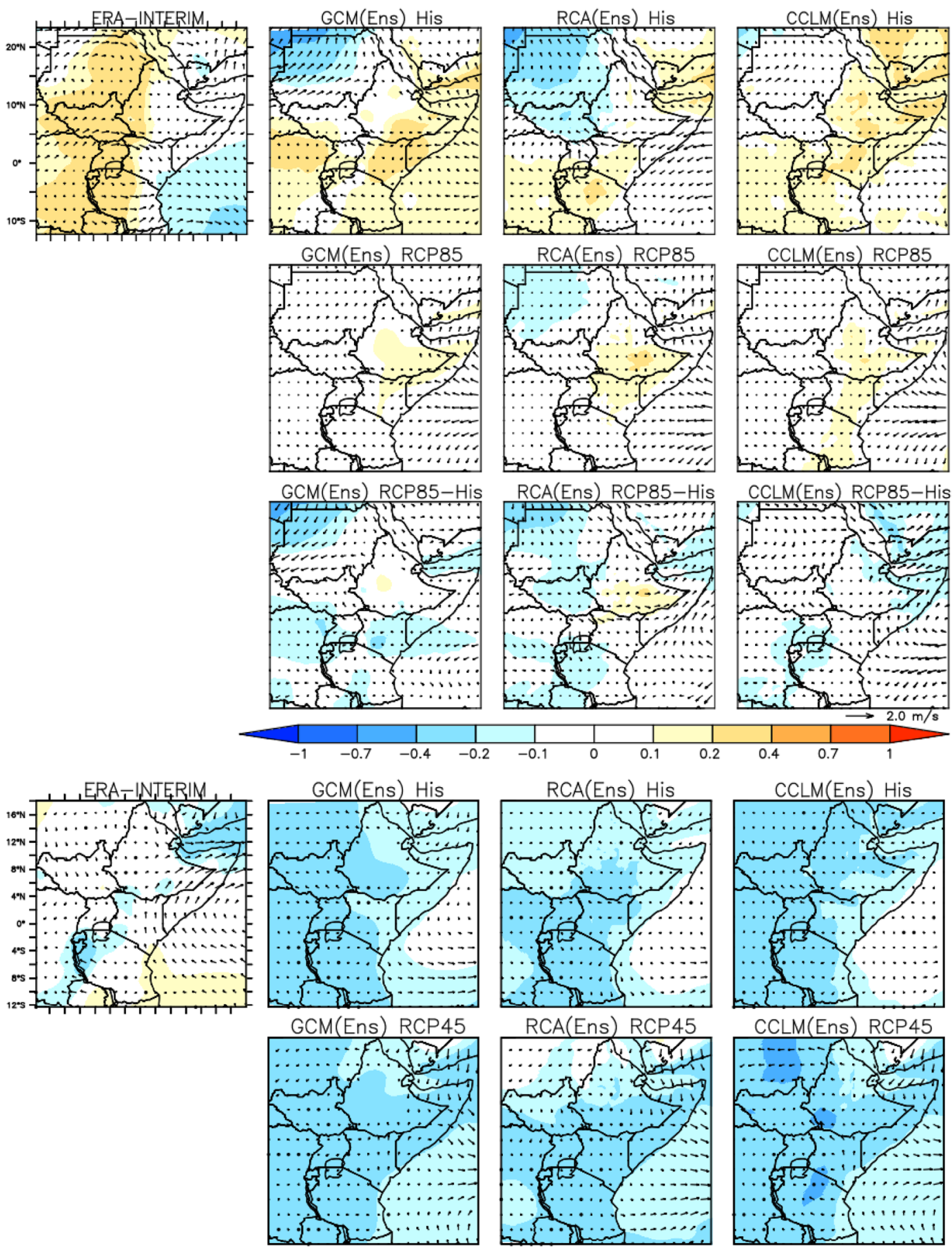

$\operatorname{CCLM}($ Ens) RCP45
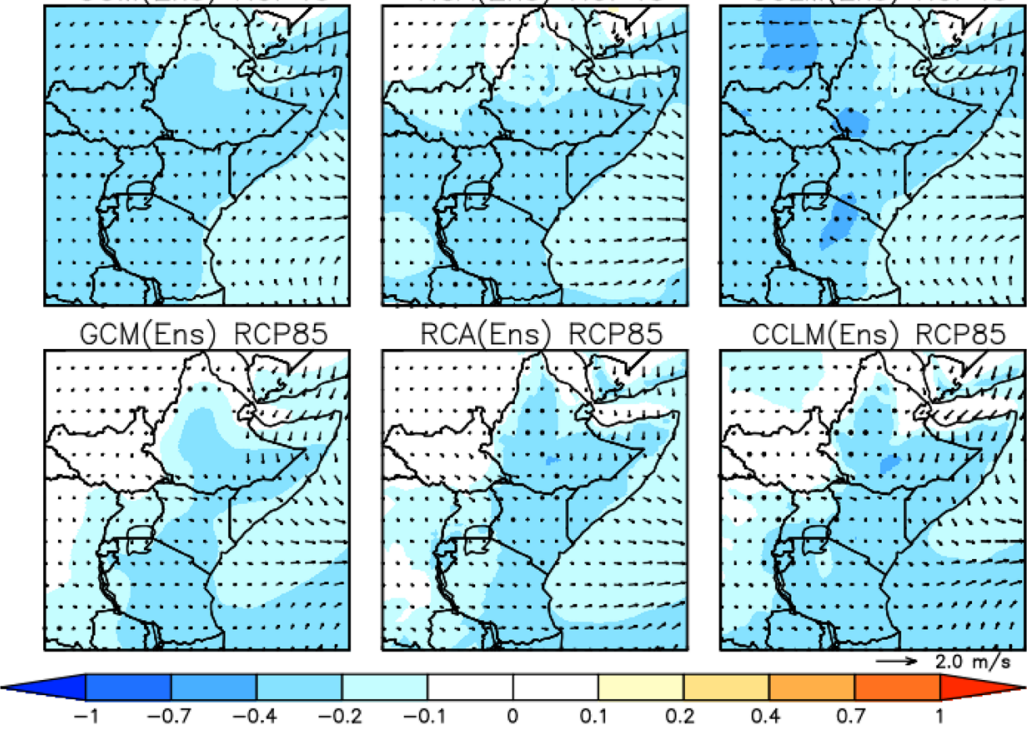

CCLM(Ens) RCP85

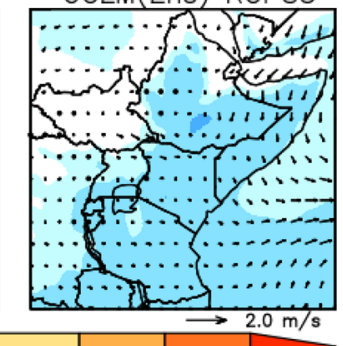


between the observed (reanalysis) and model simulations are observed for the present period. This could be due to the fact that different factors control the MAM rainfall on interannual scale. Liebmann et al. (2014) showed that different factors appear to have an influence on interannual time scales and also indicated to a disparity exists between observations and model results. Camberlin and Philippon (2002a, b), Zorita and Tilya (2002), and Pohl and Camberlin (2006) showed that interannual variability in March and April is linked to factors different from those associated with May rainfall. Their results show that March and April appear to be controlled by the zonal temperature contrast between the Indian Ocean and adjacent East African land mass by surface zonal winds, whereas May rainfall is linked to a meridional temperature contrast between the Indian Ocean and the Asian land mass and, thus, to meridional surface winds. Our analyses focus at the seasonal time scale. Both GCM and RCM ensemble mean results show positive surface pressure anomalies over most part of the region, whereas the reanalysis (ERA-Interim) shows weak negative surface pressure anomalies over western and southern parts of the region. Moreover, the reanalysis shows easterly wind anomalies over Eastern Horn of Africa, where a part of it is extended to equatorial east Africa and the other part is diverted to north westerly in equatorial Indian Ocean close to East Africa (Fig. 10 first row). In contrast, the simulations indicate southeasterly anomalies over the equatorial Indian Ocean and westerly anomalies over East horn of Africa. Discrepancy in circulations anomalies has also been demonstrated during the La Niña composites. Since there is no good agreement between simulated and observed circulation anomalies in relation to ENSO events during this particular season, discussing the future changes might not be needful.

It was evident from the previous regression and composite analysis that the OND rainfall has strong association with both ENSO and IOD events. Different studies examined the relationship between the short rains and circulation anomalies (e.g. Beltrando 1990, Goddard and Graham 1999; Hastenrath 2000; Pohl and Camberlin 2011). These studies demonstrated the critical role of the zonal circulation (Walker-type circulation) over the Indian Ocean in transmitting ENSO/IOD signal. This zonal circulation consists of opposite wind flows in the eastern and western tropical Indian Ocean. At low levels near the surface $(850 \mathrm{mb})$, westerly winds prevail, a result of a steep eastward pressure gradient. In the upper troposphere $(200 \mathrm{mb})$, easterly winds prevail. The flow forms a cell with rising motion in the east and subsidence in the west, near eastern Africa. These studies further emphasized that the most important physical mechanism in the variability of the short rains is the intensity of this cell, with the low-level westerlies playing a fundamental role in modulating this cell. Composite anomalies of SLP and $850 \mathrm{hPa}$ wind associated with El Niño
Fig. 12 OND pIOD (top) and nIOD (bottom) composite map of SLP (shaded in $\mathrm{hPa}$ ) and $850 \mathrm{hPa}$ wind (vectors in $\mathrm{m} / \mathrm{s}$ ) for historical (1976-2005) [1st row], future (2070-2099) [2nd row] and differences in between future and historical period (3rd row)

and La Niña during OND for present and future periods are shown in Fig. 11. Results of this study show that, during El Niño, positive surface pressure anomalies are observed over the western part of the region, and negative surface pressure anomalies are observed over the southwestern part of the Indian Ocean (Fig. 11, ERA-Interim). The two 850hpa wind anomalies, easterly from the equatorial Indian Ocean and westerly from the Congo rainforest basin, converge at the eastern horn of Africa. The low-level convergence leads to ascending motion and favors rainfall. The La Niña composites, on the other hand, show results that are opposite to the El Niño counterparts, in which negative SLP anomalies observed over most part of the domain. Also, during El Niño, the easterly winds over the equatorial Indian Ocean becomes weaker (even switched to westerlies) and reduces the rainfall over the region. This is in agreement with previous studies who indicated the critical role of the zonal circulation over the Indian Ocean in transmitting the ENSO signal. In the examination of the anomalous SLP and wind vectors associated with El Niño and La Niña events over the region of study, results indicate that the models capture well the anomalous patterns in the region. In future, models show a reduction in SLP anomalies particularly over the southern part of the domain. Difference in SLP and $850 \mathrm{hPa}$ wind anomalies associated with El Niño (top panel) and La Niña between the future and the historical period are in Fig. 11 third rows. During El Niño (top panel), two anomalous airstreams, southeasterly and northeasterly anomaly components, are noted over the Indian Ocean. We expect that the dipole change in rainfall teleconnection pattern might be partially linked with these two anomalous wind patterns.

Figure 12 shows composite anomalies of SLP and $850 \mathrm{hPa}$ wind associated with pIOD and nIOD in present and future periods as well as differences between the future and present period. As it is widely known, during pIOD, the western Indian Ocean becomes unusually warm and the eastern equatorial Indian Ocean unusually cold. As a result of warm SST a reduction in SLP anomaly over the western half of the Indian Ocean and converging wind anomalies over East Africa (i.e., convergence of westerly airflow over central Africa and easterly onshore anomalies from the equatorial Indian Ocean) leads to moisture convergence and increased convective activity over the region. Conversely, during nIOD years, an anomalous anticyclonic circulation occurs over the western part of the Indian Ocean with westerly wind anomalies. The anomalous anticyclonic circulations combined with the westerly wind anomalies reduce the convective activity over the region. In the present 

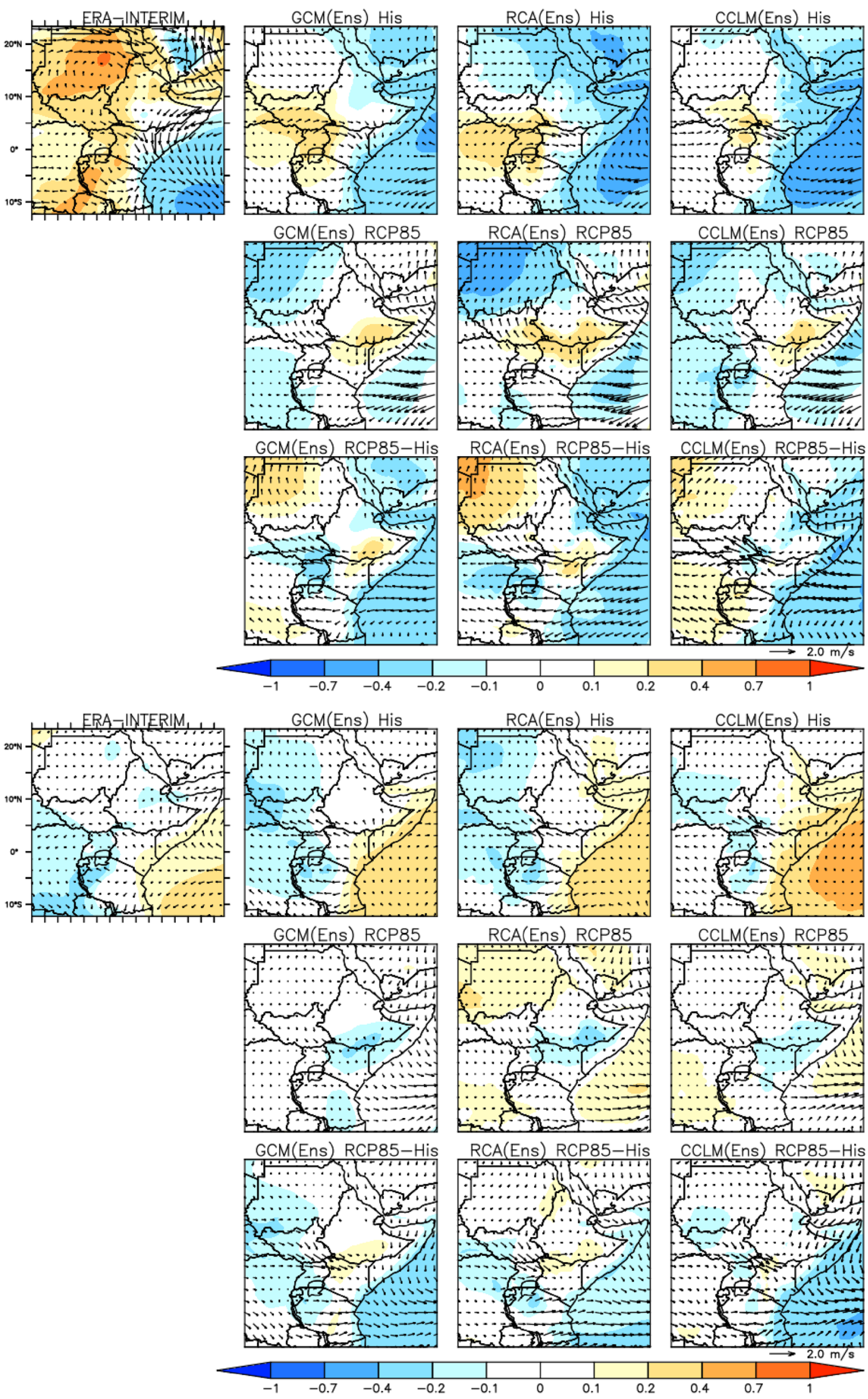
climate, all simulations reproduce the anomalous easterlies over the equatorial Indian Ocean that extends to Eastern horn of Africa during pIOD. The models also reproduce the negative SLP anomalies over the western part of the Indian Ocean and the positive SLP anomalies over the western part of the domain during pIOD, although the simulated positive SLP anomalies over western part of the domain are weaker than those in the ERA-Interim reanalysis. The anomalous circulation patterns associated with nIOD events are also captured relatively well by the regional and global ensemble means in comparison to the ERA-Interim reanalysis. In future projections, even though the general anomalous circulation patterns are similar to those of the current decades, important changes are identified. One of the prominent changes is a reduction of the SLP anomalies over the western part of the domain for both warm and cold phases of IOD (Fig. 12 second row). The present-day positive SLP anomalies associated with warm phase of IOD over the western part the domain are converted to negative anomalies. As a result, the easterly flow extends far beyond the East coast to central Africa (Fig. 12, top panel, 2rd row). In Fig. 12 (top panel third row), the differences in anomalous circulation patterns show that the easterlies from equatorial Indian Ocean extend to the southern part of Eastern Africa. Moreover, it appears that there is a reduction in SLP anomaly over western part of the domain compared to present period. This might be linked with greater warming rate of the western part of the Indian Ocean. A thorough investigation of feedback processes is required to examine changes in circulation patterns. During cold phase of IOD (Fig. 12, bottom panel, 2rd row), the positive SLP anomaly is absent in the GCM ensemble.

\section{Summary and conclusions}

Understanding how the future Eastern Africa climate responds to large-scale modes in remote regions is essential to build appropriate risk management and adaptation strategies. In this study an ensemble of regional and global simulations have been analyzed to investigate whether the Eastern Africa rainfall characteristics associated with ENSO and IOD may change in the late twenty-first century. Our analysis focuses on three rainfall seasons-JJAS, MAM and OND using data from two regional climate models (RCA and CCLM) and their driving (CMIP5) GCMs.

For the present climate, both the regional and global model ensemble means reproduce the observed dry and wet teleconnection patterns associated with ENSO and IOD. For the future climate, the spatial pattern of teleconnections between ENSO/IOD and rainfall still persist in regional and global simulations. However, important changes in the strength of the teleconnection have been identified. During
JJAS, ENSO is an important driver for rainfall variability: both regional and global ensemble simulations show higher rainfall during La Niña and lower rainfall during El Niño over the northern part of the region. During OND, the magnitude of the teleconnection pattern associated with both the ENSO and IOD is enhanced over Eastern of horn Africa (Somalia, Djibouti, and eastern part of Ethiopia and Kenya) and reduced over the southern part of Eastern Africa (most part of Tanzania, Uganda, and western Kenya). The OND rainfall teleconnections are stronger and also more consistent between the models compared to the JJAS and MAM teleconnections.

The change in teleconnections could be attributed to changes in the amplitude and frequency of the ENSO/IOD events themselves or changes to the mean state and midlatitude atmospheric circulation as a response to increase of greenhouse gases. Analyses of the change in characteristics of ENSO and IOD events (frequency and intensity) based on driving CGCMs do not show consistent patterns. Some models show an increase while others show a decrease or no change. All models agree that the frequency of El Niño events will increase, but degree of change varies from model to model. Changes in mean SSTs for the future over the tropical Pacific and Indian Ocean show an El Niño-like (positive IOD-like) warming pattern over the tropical Pacific (Indian) Ocean. This is consistent with earlier studies (Müller and Roeckner 2008; Zheng et al. 2013; Cai et al. 2013 and others). High rainfall seasons over the eastern horn of Africa attributable to ENSO and IOD phases are probably linked to a warmer western region of the Indian Ocean in future compared to the present.

Assessment of the projected seasonal mean rainfall over the domain varies depending on the sub-region and season. During OND season, there is good agreement between models of an increase in mean rainfall over the equatorial part of the Eastern Africa. These OND increases are consistent with observational studies suggesting warming in the Western Indian Ocean is responsible. During JJAS and MAM rainfall seasons, a decrease in rainfall is projected over most parts of the region although the model agreement is not as high as OND season. This drying appears consistent with observational studies focused on paleoclimate data (Tierney et al. 2013, 2015) and station data (Funk et al. 2015), as well as earlier RCM analyses by Cook and Vizy (2013).

The main findings of the analysis on future changes in rainfall associated with ENSO, IOD and changes in the mean state over Eastern Africa for the three rainfall seasons are summarized in the Table 2.

Overall, the results from this study provide important information about the future changes in rainfall associated with ENSO and IOD as well as changes in the mean state over Eastern Africa. The findings have an important 
Table 2 Summary of future changes in rainfall associated with ENSO, IOD and changes in the mean state over Eastern Africa for the three rainfall seasons (JJAS, MAM and OND)

\begin{tabular}{|c|c|c|c|}
\hline & ENSO & IOD & Change in Mean \\
\hline JJAS & $\begin{array}{l}\text { El Niño teleconnection captured well on the } \\
\text { historical period } \\
\text { Future projections indicate enhancement of } \\
\text { ENSO and rainfall relationship (mainly } \\
\text { associated with La Niña) }\end{array}$ & & $\begin{array}{l}\text { Drier conditions are expected over most of } \\
\text { the region }\end{array}$ \\
\hline MAM & $\begin{array}{l}\text { Weak ENSO/IOD teleconnections, and } \\
\text { large discrepancies between observed and } \\
\text { simulations in historical period. Models } \\
\text { project stronger ENSO telecoonections } \\
\text { in future }\end{array}$ & & $\begin{array}{l}\text { Drier conditions are expected over most part } \\
\text { of the region }\end{array}$ \\
\hline OND & $\begin{array}{l}\text { ENSO teleconnections captured well on } \\
\text { the historical period. Future projections } \\
\text { indicate stronger ENSO teleconnection } \\
\text { patterns in the Eastern East Africa and } \\
\text { weaker in the southern East Africa }\end{array}$ & $\begin{array}{l}\text { IOD teleconnections reproduced well on } \\
\text { the historical period. Future projections } \\
\text { indicate stronger IOD teleconnection } \\
\text { patterns in the Eastern East Africa and } \\
\text { weaker in the southern East Africa }\end{array}$ & $\begin{array}{l}\text { Wetter conditions are expected over most of } \\
\text { the region }\end{array}$ \\
\hline
\end{tabular}

implication for water and agricultural managers and policies in the region. It is evident from this analysis that OND rainfall is projected to increase while MAM and JJAS rains are projected to decrease over most areas of the region. The decrease in MAM and JJAS rains, combined with the rapid population growth and rise in global average temperature, will have a serious impact on water demand, crop yield and food security in the region. On the other hand, the increase rainfall during OND creates opportunities for water storage and enhanced crop/livestock production. Therefore, appropriate risk management and adaptation strategies should be considered and implemented to reduce the risk of future conditions. Since most of the cropped areas in the region are rain-fed, development of water storage and irrigation would be the most crucial step for maintaining crop productivity and ensuring future food security. On the other hand, switching to drought resilient crops and altering the timing of cropping activities would be alternative options to be considered to cope with the changing climate.

The study also provides additional implications for seasonal forecasting in future, as there is still a strong reliance on empirical relationships. This is particularly very relevant to the regional climate prediction centres like the IGAD Climate Prediction and Application Centre (ICPAC) and national meteorological agencies in East Africa. Although the study provides essential information on how the future Eastern Africa climate responds to largescale modes in remote regions, the physical mechanisms responsible for the change in teleconnection patterns in the future are not well known. Further experimental analysis e.g. through an investigation of feedback processes, is required to further enhance our understanding of these physical processes.
Open Access This article is distributed under the terms of the Creative Commons Attribution 4.0 International License (http://creativeco mmons.org/licenses/by/4.0/), which permits unrestricted use, distribution, and reproduction in any medium, provided you give appropriate credit to the original author(s) and the source, provide a link to the Creative Commons license, and indicate if changes were made.

\section{References}

Anyah RO, Semazzi FH (2007) Variability of East African rainfall based on multiyear RegCM3 simulations. Int J Climatol 27(3):357-371

Bahaga TK, Tsidu M, Kucharski GF, Diro GT (2015) Potential predictability of the sea-surface temperature forced equatorial East African short rains interannual variability in the 20 th century. Q J R Meteorol Soc 141(686):16-26

Behera SK, Luo JJ, Masson S, Delecluse P, Gualdi S, Navarra A, Yamagata T (2005) Paramount impact of the Indian Ocean dipole on the East African short rains: a CGCM study. J Clim 18(21):4514-4530

Beltrando G (1990) Space-time variability of rainfall in april and October-November over East Africa during the period 1932-1983. Int J Climatol 10(7):691-702. https://doi.org/10.1002/joc.33701 00704

Black E (2005) The relationship between Indian Ocean sea-surface temperature and East African rainfall. Philos Trans R Soc Lond A Math Phys Eng Sci 363(1826):43-47

Cai W, Zheng XT, Weller E, Collins M, Cowan T, Lengaigne $\mathrm{M}$ et al (2013) Projected response of the Indian Ocean Dipole to greenhouse warming. Nat Geosci 6(12):999-1007

Cai W, Borlace S, Lengaigne M, Van Rensch P, Collins M, Vecchi G et al (2014a) Increasing frequency of extreme El Niño events due to greenhouse warming. Nat Clim Chang 4(2):111-116

Cai W, Santoso A, Wang G, Weller E, Wu L, Ashok K et al (2014b) Increased frequency of extreme Indian Ocean Dipole events due to greenhouse warming. Nature 510(7504):254-258

Cai W, Wang G, Santoso A, McPhaden MJ, Wu L, Jin FF et al (2015) Increased frequency of extreme La Niña events under greenhouse warming. Nat Clim Chang 5(2):132-137 
Camberlin P (1997) Rainfall anomalies in the source region of the Nile and their connection with the Indian summer monsoon. $\mathbf{J}$ Clim 10(6):1380-1392

Camberlin P, Philippon N (2002a) The east african march-may rainy season: associated atmospheric dynamics and predictability over the 1968-97 period. J Clim 15(9):1002-1019

Camberlin P, Philippon N (2002b) The East African March-May rainy season: associated atmospheric dynamics and predictability over the 1968-97 period. J Clim 15(9):1002-1019. https:// doi.org/10.1175/1520-0442(2002)015<1002:TEAMMR > 2.0 $\mathrm{CO} ; 2$

Camberlin P, Moron V, Okoola RE, Philippon N, Gitau W (2009a) Components of rainy seasons' variability in equatorial East Africa: onset, cessation, rainfall frequency and intensity. Theor Appl Climatol 98(3-4):237-249. https://doi.org/10.1007/s0070 4-009-0113-1

Camberlin P, Moron V, Okoola R, Philippon N, Gitau W (2009b) Components of rainy seasons variability in equatorial east africa: onset, cessation, rainfall frequency and intensity. Theor Appl Climatol 98(3-4):237-249

Camberlin P, Fontaine B, Louvet S, Oettli P, Valimba P (2010) Climate adjustments over Africa accompanying the Indian monsoon onset. J Clim 23(8):2047-2064. https://doi.org/10.1175/2009JCLI3302.1

Clark C, Webster P, Cole J (2003) Interdecadal variability of the relationship between the indian ocean zonal mode and east african coastal rainfall anomalies. J Clim 16(3):548-554

Collins M, An SI, Cai W, Ganachaud A, Guilyardi E, Jin FF et al (2010) The impact of global warming on the tropical Pacific Ocean and El Niño. Nat Geosci 3(6):391-397

Cook KH, Vizy EK (2013) Projected changes in East African rainy seasons. J Clim 26(16):5931-5948

Diro GT, Grimes DIF, Black E (2011) Teleconnections between Ethiopian summer rainfall and sea surface temperature: part I-observation and modelling. Clim Dyn 37(1-2):103-119

Dosio A, Panitz H-J (2016) Climate change projections for CORDEXAfrica with COSMO-CLM regional climate model and differences with the driving global climate, Clim Dyn 46:1599-1625. https://doi.org/10.1007/s00382-015-2664-4

Endris HS, Omondi P, Jain S, Lennard C, Hewitson B, Chang'a L, Awange JL, Dosio A, Ketiem P, Nikulin G, Panitz HJ, Büchner M, Stordal F, Tazalika L (2013) Assessment of the performance of CORDEX regional climate models in simulating East African rainfall. J Clim 26(21):8453-8475

Endris HS, Lennard C, Hewitson B, Dosio A, Nikulin G, Panitz H-J (2016) Teleconnection responses in multi-GCM driven CORDEX RCMs over Eastern Africa. Clim Dyn 46(9-10):2821-2846. https ://doi.org/10.1007/s00382-015-2734-7

Funk C, Dettinger MD, Michaelsen JC, Verdin JP, Brown ME, Barlow M, Hoell A (2008) Warming of the Indian Ocean threatens eastern and southern African food security but could be mitigated by agricultural development. Proc Natl Acad Sci 105(32):11081-11086

Funk C, Hoell A, Shukla S, Blade I, Liebmann B, Roberts JB et al (2014) Predicting East African spring droughts using Pacific and Indian Ocean sea surface temperature indices. Hydrol Earth Syst Sci 18(12):4965

Funk C, Nicholson SE, Landsfeld M, Klotter D, Peterson P, Harrison L (2015) The centennial trends greater horn of Africa precipitation dataset. Scientific data 2:150050

Goddard L, Graham NE (1999) Importance of the Indian Ocean for simulating rainfall anomalies over eastern and southern Africa. J Geophys Res: Atmospheres 104(D16):19099-19116

Gissila T, Black E, Grimes D, Slingo J (2004) Seasonal forecasting of the Ethiopian summer rains. Int J Climatol 24(11):1345-1358

Hastenrath S (2000) Zonal circulations over the equatorial Indian Ocean. J Clim 13(15):2746-2756 https://doi. org/10.1175/1520-0442(2000)013<2746:ZCOTEI >2.0.CO;2
Hastenrath S (2007) Circulation mechanisms of climate anomalies in East Africa and the equatorial Indian Ocean. Dyn Atmos Oceans 43(1):25-35

Hastenrath S, Polzin D, Camberlin P (2004) Exploring the predictability of the 'Short Rains' at the coast of East Africa. Int J Climatol 24:1333-1343. https://doi.org/10.1002/joc.1070

Hastenrath S, Nicklis A, Greischar L (1993) Atmospheric-hydrospheric mechanisms of climate anomalies in the western equatorial Indian Ocean. J Geophys Res: Oceans 98(C11):20219-20235

Hoell A, Funk C (2014) Indo-Pacific sea surface temperature influences on failed consecutive rainy seasons over eastern Africa. Clim Dyn 43(5-6):1645-1660

Indeje M, Semazzi F, Ogallo L et al (2000) Enso signals in east african rainfall seasons. Int J Climatol 20(1):19-46

Intergovernmental Panel on Climate Change (IPCC) (2007) In: Solomon S et al (eds) Climate change 2007: the physical science basis, working group I contribution to the fourth assessment report of the IPCC. Cambridge University Press

Intergovernmental Panel on Climate Change (IPCC) (2013) In: Stocker TF et al (eds) Climate change 2013: the physical science basis, working group I in contribution to the fifth assessment report of the IPCC. Cambridge University Press

Korecha D, Barnston AG (2007) predictability of june-september rainfall in ethiopia. Mon Weather Rev 135(2):628-650

Kug JS, An SI, Ham YG, Kang IS (2010) Changes in El Niño and La Niña teleconnections over North Pacific-America in the global warming simulations. Theor Appl Climatol 100(3-4):275-282

Langenbrunner B, Neelin JD (2013) Analyzing enso teleconnections in cmip models as a measure of model fidelity in simulating precipitation. J Clim 26:4431-4446. https://doi.org/10.1175/ JCLI-D-12-00542.1

Lau NC, Leetmaa A, Nath MJ (2008) Interactions between the responses of North American climate to El Nino-La Nina and to the secular warming trend in the Indian-Western Pacific Oceans. J Clim 21(3):476-494

Liebmann B et al (2014) Understanding recent eastern Horn of Africa rainfall variability and change. J Clim 27:8630-8645. https://doi.org/10.1175/JCLI-D-13-00714.1

Liebmann B, Bladé I, Funk C, Allured D, Quan XW, Hoerling M et al (2017) Climatology and interannual variability of boreal spring wet season precipitation in the eastern Horn of Africa and implications for its recent decline. J Clim 30(10):3867-3886

Lyon B (2014) Seasonal drought in the greater horn of africa and its recent increase during the March-May long rains. J Clim 27(21):7953-7975

Lyon B, DeWitt DG (2012) A recent and abrupt decline in the east African long rains. Geophys Res Lett 39:L02702. https://doi. org/10.1029/2011GL050337

Lyon B, Barnston AG, DeWitt DG (2014) Tropical pacific forcing of a 1998-1999 climate shift: observational analysis and climate model results for the boreal spring season. Clim Dyn 43(3-4):893-909

Meehl GA, Teng H (2007) Multi-model changes in El Niño teleconnections over North America in a future warmer climate. Clim Dyn 29(7-8):779-790

Meehl GA, Teng H, Branstator G (2006) Future changes of El Niño in two global coupled climate models. Clim Dyn 26(6):549-566

Meinshausen M, Smith SJ, Calvin K, Daniel JS, Kainuma MLT, Lamarque JF et al (2011) The RCP greenhouse gas concentrations and their extensions from 1765 to 2300. Clim Chang 109(1-2):213-241

Merryfield WJ (2006) Changes to ENSO under CO2 doubling in a multimodel ensemble. J Clim 19(16):4009-4027

Moron V, Camberlin P, Robertson AW (2013) Extracting subseasonal scenarios: an alternative method to analyze 
seasonal predictability of regional-scale tropical rainfall. J Clim 26(8):2580-2600. https://doi.org/10.1175/JCLI-D-12-00357.1

Moss RH, Edmonds JA, Hibbard KA, Manning MR, Rose SK, Van Vuuren DP et al (2010) The next generation of scenarios for climate change research and assessment. Nature 463(7282):747-756

Müller WA, Roeckner E (2008) ENSO teleconnections in projections of future climate in ECHAM5/MPI-OM. Clim Dyn 31(5):533-549

Mutai CC, Ward MN (2000) East African rainfall and the tropical circulation/convection on intraseasonal to interannual timescales. J Clim 13(22):3915-3939. https://doi. org/10.1175/1520-0442(2000)013<3915:EARATT > 2.0.CO;2

Mutai C, Ward M, Colman A (1998) Towards the prediction of the east africa short rains based on sea-surface temperature-atmosphere coupling. Int J Climatol 18(9):975-997

Nicholson SE (1996) A review of climate dynamics and climate variability in Eastern Africa. In: Johnson TC, Odada EO (eds) The limnology, climatology and paleoclimatology of the East African Lakes. Gordon and Breach, Philadelphia, pp 25-56

Nicholson SE (2017) Climate and climatic variability of rainfall over Eastern Africa. Rev Geophys. https://doi.org/10.1002/2016RG000544

Nicholson S, Kim J (1997) The relationship of the el nino-southern oscillation to African rainfall. Int J Climatol 17(2):117-135

Nikulin G, Jones C, Giorgi F, Asrar G, Büchner M, Cerezo-Mota R et al (2012) Precipitation climatology in an ensemble of CORDEXAfrica regional climate simulations. J Clim 25(18):6057-6078

Ogallo L, Janowiak J, Halpert M (1988) Teleconnection between seasonal rainfall over east africa and global sea surface temperature anomalies. JMSJAU 66(6):807-822

Ogwang BA, Chen H, Li X, Gao C (2016) Evaluation of the capability of RegCM4 in simulating East African climate. Theor Appl Climatol 124(1-2):303-313

Otieno VO, Anyah RO (2013) CMIP5 simulated climate conditions of the Greater Horn of Africa (GHA). Part II: projected climate. Clim Dyn 41(7-8):2099-2113

Philippon N, Camberlin P, Fauchereau N (2002) Empirical predictability study of October-December East African rainfall. QJR Meteorol Soc 128:2239-2256. https://doi.org/10.1256/qj.01.190

Philipps J, McIntyre B (2000) ENSO and interannual variability in Uganda: implications for agricultural management. Int J Climatol 20:171-182

Pohl B, Camberlin P (2006) Influence of the Madden-Julian Oscillation on East African rainfall: II. March-May season extremes and interannual variability. Q J R Meteorol Soc 132(621, B):25412558. https://doi.org/10.1256/qj.05.223

Pohl B, Camberlin P (2011) Intraseasonal and interannual zonal circulations over the equatorial Indian Ocean. Theor Appl Climatol 104(1-2):175-191. https://doi.org/10.1007/s00704-010-0336-1

Ropelewski C, Halpert M (1987) Global and regional scale precipitation patterns associated with the El Niño/southern oscillation. Mon Weather Rev 115(8):1606-1626

Rowell DP, Ininda JM, Ward MN (1994) The impact of global sea surface temperature patterns on seasonal rainfall in East Africa. In: Proc. int. conf. on monsoon variability and prediction, Trieste, Italy, WMO, Geneva, Switzerland, pp 666-672

Rowell DP, Folland CK, Maskell K, Ward MN (1995) Variability of summer rainfall over tropical north Africa (1906-1992): observations and modelling. Q J R Meteorol Soc 121(523):669-704. https ://doi.org/10.1002/qj.49712152311

Rowell DP, Booth BB, Nicholson SE, Good P (2015) Reconciling past and future rainfall trends over east Africa. J Clim 28(24):9768-9788

Saji NH, Goswami BN, Vinayachandran PN, Yamagata T (1999) A dipole mode in the tropical Indian Ocean. Nature 401(6751):360-363
Santoso A, Cai W, Collins M, McPhaden M, Jin FF, Guilyardi E et al (2015) ENSO extremes and diversity: dynamics, teleconnections, and impacts. Bull Am Meteor Soc 96(9):1969-1972

Segele ZT, Lamb PJ, Leslie LM (2009a) Large-scale atmospheric circulation and global sea surface temperature associations with horn of Africa June-September rainfall. Int J Climatol 29(8):1075-1100

Segele ZT, Leslie LM, Lamb PJ (2009b) Evaluation and adaptation of a regional climate model for the Horn of Africa: rainfall climatology and interannual variability. Int J Climatol 29(1):47-65

Shongwe ME, van Oldenborgh GJ, van den Hurk B, van Aalst M (2011) Projected changes in mean and extreme precipitation in Africa under global warming. Part II: East Africa. J Clim 24(14):3718-3733

Smith TM, Reynolds RW, Peterson TC, Lawrimore J (2008) Improvements to NOAA's historical merged land-ocean surface temperature analysis (1880-2006). J Clim 21(10):2283-2296

Souverijns N, Thiery W, Demuzere M, van Lipzig NPM (2016) Drivers of future changes in East African precipitation. Environ Res Lett 11:114011

Steinhoff DF, Monaghan AJ, Clark MP (2015) Projected impact of twenty-first century ENSO changes on rainfall over Central America and northwest South America from CMIP5 AOGCMs. Clim Dyn 44(5-6):1329-1349

Stevenson S, Fox-Kemper B, Jochum M, Neale R, Deser C, Meehl G (2012) Will there be a significant change to El Niño in the twentyfirst century? J Clim 25(6):2129-2145

Sun L, Semazzi FH, Giorgi F, Ogallo L (1999) Application of the NCAR regional climate model to eastern Africa: 1. Simulation of the short rains of 1988. J Geophys Res Atmos 104(D6):6529-6548

Tierney JE, Smerdon JE, Anchukaitis KJ, Seager R (2013) Multidecadal variability in EastAfrican hydroclimate controlled by the Indian Ocean. Nature 493:389-392. https://doi.org/10.1038/natur e11785

Tierney JE, Ummenhofer CC, DeMenocal PB (2015) Past and future rainfall in the horn of Africa. Sci Adv 1:e1500682

Trenberth KE (1997) The definition of El Niño. Bull Am Meteor Soc 78(12):2771-2777

Vecchi GA, Soden BJ (2007) Global warming and the weakening of the tropical circulation. J Clim 20(17):4316-4340

Verdin J, Funk C, Senay G, Choularton R (2005) Climate science and famine early warning. Philos Trans R Soc B Biol Sci 360(1463):2155-2168

Vigaud N, Lyon B, Giannini A (2017) Sub-seasonal teleconnections between convection over the Indian Ocean, the East African long rains and tropical Pacific surface temperatures. Int J Climatol 37(3):1167-1180

Williams AP, Funk C (2011) A westward extension of the warm pool leads to a westward extension of the walker circulation, drying eastern Africa. Clim Dyn 37(11-12):2417-2435

Yang W, Seager R, Cane MA, Lyon B (2014) The east african long rains in observations and models. J Clim 27(19):7185-7202

Yang W, Seager R, Cane MA, Lyon B (2015) The annual cycle of East African precipitation. J Clim 28(6):2385-2404

Zelle H, van Oldenborgh J, Burgers G, G., \& Dijkstra H (2005) El Niño and greenhouse warming: results from ensemble simulations with the NCAR CCSM. J Clim 18(22):4669-4683

Zhang Y, Qian Y, Dulière V, Salathé Jr EP, Leung LR (2012) ENSO anomalies over the Western United States: present and future patterns in regional climate simulations. Clim Chang 110(1-2):315-346

Zheng XT, Xie SP, Du Y, Liu L, Huang G, Liu Q (2013) Indian Ocean dipole response to global warming in the CMIP5 multimodel ensemble*. J Clim 26(16):6067-6080

Zorita E, Tilya FF (2002) Rainfall variability in northern Tanzania in the March-May season (long rains) and its links to large-scale climate forcing. Clim Res 20(1):31-40. https://doi.org/10.3354/ cr020031 